Florida International University FIU Digital Commons

FIU Electronic Theses and Dissertations

University Graduate School

1984

\title{
A study of the impact of field experience in hospitality education
}

Peter Okon Agbomi

Florida International University

DOI: $10.25148 /$ etd.FI13101536

Follow this and additional works at: https://digitalcommons.fiu.edu/etd

Part of the Hospitality Administration and Management Commons

\section{Recommended Citation}

Agbomi, Peter Okon, "A study of the impact of field experience in hospitality education" (1984). FIU Electronic Theses and Dissertations. 1253.

https://digitalcommons.fiu.edu/etd/1253

This work is brought to you for free and open access by the University Graduate School at FIU Digital Commons. It has been accepted for inclusion in FIU Electronic Theses and Dissertations by an authorized administrator of FIU Digital Commons. For more information, please contact dcc@fiu.edu. 


\section{$\underline{\text { ABSTRACT }}$}

A STUDY OF THE IMPACT OF FTELD EXPERIENCE IN HOSPITALITY EDUCATION

BY

PETER OKON AGBOMI

The purpose of this study was to find out the impact of field experience in hospitality education and whether such field experience and others such as semi-practicum, the cooperative, and the work study programs will not play an important role of a closer alliance between the academic and the hospitality industry.

II. If it is justifiable to say that it is possible to provide field experience which will enhance the professionally oriented course work, while educators and employers strive to design curriculum that is needed to meet the educational and the industry demands and goals. 
THE IMPACT OF FIELD EXPERIENCE IN HOSPITALITY EDUCATION

\author{
by \\ PETER OKON AGBOMI
}

A hospitality project submitted in partial fulfillment of the requirement for the degree of

MASTER OF SCIENCE

in

HOTEL AND FOOD SERVICE MANAGEMENT

at

FLORIDA INTERNATIONAL UNIVERSITY

Committee in charge:

Assistant Professor Mickey Warner, Chairman

Assistant Professor Steven V. Moll 
TO: Assistant Professors Mickey Warner and Steven V. Moll

This Hospitality Project, having been approved in respect to form and mechanical execution, is referred to you for judgement upon its substantial merit.

Dean Anthony G. Marshall

School of Hospitality Management

The Hospitality Project of Peter Okon Agbomi is approved.

Assistant Professor Mickey Warner

Date of Examination:

Assistant Professor Steven V. Moll 


\title{
THE IMPACT OF FIELD EXPERIENCE IN HOSPITALITY EDUCATION
}

\author{
by \\ PETER OKON AGBOMI
}

A Hospitality Project submitted in partial fulfillment of the requirement for the degree of

\section{MASTER OF SCIENCE}

in

HOTEL AND FOOD SERVICE MANAGEMENT

at

FLORIDA INTERNATIONAL UNIVERSITY

1984 


\section{ACKNOWLEDGEMENTS}

Special thanks to my parents, Elder Emman and Lucy Agbomi for their love and patience.

To Professors Mickey Warner and Steve Moll, for their intellectual stimulation and guidance.

To My Boss, Jim Johnson and special friend, Jim Maney for making available to me all the necessary tools to make this project a success.

"No man is an Island", Sixtus Ikogor you proved the truism in this statment - this one is for you "Enoooh". Pat Pritchett - I love you. 
I. THE PROBLEM AND ITS SETTING
A. The statement of the Problem
B. The Sub-Problem
1. The First Sub-Problem
2. The Second Sub-Problem
C. The Hypotheses
1. The First Hypotheses
2. The Second Hypotheses
D. Delimitations
E. Definition of Terms
F. Assumptions
1. The First Assumption
2. The Second Assumption
G. Importance of the study

II. THE REVIEW OF RELATED LITERATURE

A. Historical Review

B. The Demand of Multi-Unit Management

C. Changing Programs in Hospitality Education

D. Initiating Field Experience.

E. Support by Academic Administrators, etc.

F. Field Experience and Other Modified Forms of Training

G. Performance, Goals and Management

H. Improving Employees (Interns) Attitudes

I. Customer Demands

J. Where to start

K. The Views Held by Hospitality Industry Personnel

L. Problems Involved in Field Experience

1. Human Relations

2. Evaluation Problems

3. Length of Training Programs

III. THE DATA AND THE TREATMENT OF THE DATA

A. The Criteria Governing the Admissibility of the Data

B. The Research Methodology

C. The Specific Treatment of the Data for Each Sub-Problem

1. Sub-Problem one

a. Data Needed

b. Location of the Data

c. Means of Obtaining the Data

d. Treatment of the Data 
2. Sub-Problem Two

a. Data Needed

b. Location of Data

c. Means of Obtaining Data

d. Treatment of Data

IV. GENERAL PROCEDURE

A. The Formulation of the Sample

B. The Measurement Instrument

1. Appendix A

2. Appendix $B$

V. RESULTS

Analysis of Questionnaire

Summary and Conclusion

Recommendation

VI. APPENDICES

Selected Bibliography

Vitae 
I. THE PROBLEM AND ITS SETTING 
A. THE STATEMENT OF THE PROBLEM

This research proposes to identify and analyze the impact of field experience in hospitality education.

B. THE SUB-PROBLEM

1. The first sub-problem is the identification of the impact of field experience in hospitality education.

2. The second sub-problem is analyzing of the impact of field experience in hospitality education.

C. THE HYPOTHESES

1. The first hypothesis is that field experience and other modified experiences such as seminar-practicum, the cooperative, and the work study programs will not play an important role of closer alliance between the academic and the hospitality industry.

2. The second hypothesis is that it is possible to offer courses in field experience, other modified experiences such as seminar-practicum, the cooperative which will enhance the students' professionally oriented course work, while educators, academic administrators, and employers strive to design a common curriculum that is needed to meet the educational and hospitality industry goals. 
D. THE DELIMITATIONS

The researcher will not attempt to survey all the employers, graduates, and academic administrators of two and four year colleges which award diplomas and degrees in Hotel Restaurant and Industrial Foodservice Management in the United States.

It will not provide a common curriculum which is needed to meet the educational and field experience in hospitaltiy education and the industry at large.

E. THE DEFINITION OF TERMS

Academic Administrator - In this paper, academic administrator refers to deans, chairpersons, and coordinators of the School of Hospitality Management.

Attitude - Attitudes are the various state of minds of individuals towards values, and persons or things. Attitudes are said to be constructed from a particular vantage pojnt. 1

Communication System - Communication systems is defined as a necessary vehicle for informing the employees/ interns of the policies and objectives of the organization as well as the methods of implementation. 2

${ }^{1}$ William T. Morgan. "Definition and Effects of Attitudes". Hospitality Personnel Management, CBI Publishing Company, Inc., Boston, Massachusetts, 1979, p. 149.

2william T. Morgan. "Types of Communications", Hospitality Personnel Management, CBI Publishing Company, Inc., Boston, Massachusetts, 1979, pp. 126-127. 
Evaluation - Evaluation is the process in which the performance of the interns/employees is measured in proportion to the standards and norms of the operation and that of the industry at large. It is used to determine those who have attained the highest performance in the course in the case of interns (for a higher grade where applicable) and for promotion in the case of employees. Field Experience - In this context, field experience is defined as a planned, continuous organization and wide process supported by educators and employers, and is aimed at developing the skills and attitudes of potential hospitality educators and managers. It is implemented for the purpose of enhancing the organization's climate, equality of work life, service to the guests, and productivity through the use of modern management methods. ${ }^{3}$

Work Study Program - Work study programs are designed as hospitality industry specific management training programs used to explore the actual practices of employees and interns and comparing them to desired practices and emphasizing methods that will close the gap between the two. Work study is generally led by a facilitator whose role is to generate knowledge and experience based on group needs and dynamics.

\footnotetext{
3 Eugene A. Ference. "Towards a Definition of Training", The Cornell Hotel Restaurant Association, November, 1980, p. 25 .
} 
CHRIE - These initials, CHRIE, represent the Council on Hotel Restaurant and Institutitonal Education. ${ }^{4}$ HRIM - The initials HRIM represent the Hotel Restaurant and Institutional Management. 5

Curriculum - Curriculum is the various courses offered by an educational institution. Curriculum is also used to give a short account of one's career and qualifications prepared typically by an applicant for a position in hospitality industry.

\section{F. ASSUMPTIONS}

1. The first assumption is that field experience and other modified experiences, such as semi-practicum, the cooperative and the work study program, provide a setting through which the students can apply their academic knowledge in and to hospitality fields, respectively.

2. The second assumption is that most hospitality institutions that require field experience have not come up with a uniform and established criteria for grading.

4 The Journal of Hospitality Education, Volume 1, June 1976, ${ }^{5}$ Ibid, p. 2 . 


\section{G. IMPORTANCE OF THE STUDY}

The field experience as a component of the hospitality management educational curriculum is certain to grow in importance as the demand for more efficient management personnel becomes eminent. The hospitality management academic administrators and educators will beforced to include and adopt programs that can produce the efficient leaders needed in the industry.

Often times, graduate students of the hospitality industry management, have been known to face barriers duing search for employment. The reasons cited for such barriers were due in part for the lack of field experience and that most of the professional courses taught in shcools place emphasis on concepts rather than the realities that exist in the business world. The importance attached to the field experience by the employers cannot be overlooked by the hospitaltiy academic administrators, educators, and students.

To stress this further, previous studies have shown that it takes about $\$ 500$ and more to train an employee in this industry.

The industry is known to have a very high turnover rate. The 1980's have proven to be an era of inflation, high unemployment rate and recessionary period. It is known to be an era of computers. 
The changing economic conditions of modern hospitality business may be brought into sharper focus by noting some of the major needs and chanllenges facing the manager of tomorrow. This implies that the hospitality administrators, educators and students msut not only be aware of these changes in external economic conditions, but must restructure and design a new curriculum that will stand the test of the $80 \mathrm{\prime}$.

The impact of the hospitality industry in developing countries is well established. Its contribution to the country's economy in terms of revenue and employment is unquestionable. Most of our hospitaltiy management in-: stitutions recruit half of its students from foreign countries. A majority of these students are known to be sponsored by some type of government agency. Upon completion of the program, they return to their countries to take top management positions in the tourism industry. The question arises, how efficient can such managers and administrators perform if they had no previous field experience while in school?

It is for these reasons and others that the research on field experience and other modified experiences such as seminar practicum, the cooperative and the work study program in hospitality management education, becomes vital. 
The research will strive to view what role the field experience will play in management personnel upon completion of the program, significance of such a program to foreign students and finally to the employer of the industry. 
II. THE REVIEW OF RELATED LITERATURE 


\section{A. HISTORICAL REVIEW}

The management tradition of the hospitality industry has long focused on the manager's operational expertise. Field experience and training has generally consisted of familiarizing the trainee with all the working stations and line positions in an operation's advancement has largely been based on experience in operations. Thus, the focus has been on technical management skills exercised at the unit level. 6

The recent years have been a series of cumulative changes in the industry. In 1960, for instance, the foodservice industry was dominated by independents, just as was the lodging industry in the 1950's. Today, the lodging industry is completely dominated by large national systems and the one hundred foodservice chains in the United States operation, twenty nine percent of all United States foodservice volume. 7 From an industry once dominated by faceto-face personal relationships, we have seen an evolution toward complex operating systems that compete in a national rather than a local market place and that are managed by large, complex organizations.

6 Thomas Powrs. "The Emergence of New Breed of Operation: Complex Foodservice System", The Cornell Hotel and Restaurant Administration Quarterly, 20, No. 3, Nov. 1979, pp. 49-58. 71983 Dynamics of the Chain Restaurant Market (Chicago, III.: Technomic Consultants, 1982), p.3. 
It is this revolution that Wyckoff and Sasser noted, that at some point along this path, the industry's need for professional management becomes crucial. 8 A management tradition focused on technicals and unit operations, however, many actually hinder companies as they try to move toward development of a more professional management team. Many hospitality institutions and companies have committed extensive resources of central training institutions, large field-training staffs, and audio-visual training support. While such field experience/training efforts have their place, these companies commonly fail to recognize that an entirely different form of training is required to develop potential and senior managers.

\section{B. THE DEMAND OF MULTI-UNIT MANGEMENT}

The managers or interns who move out of unit management to assume multi-unit responsibility, has moved from an environment entailing routine operating problems requiring analytical and conceptual skills. Hence, the managers who are responsible for results in several units cannot rely on personal contact with workers to inspire results; instead he or she must emphasize entirely different kinds of human skills==those associated with organization-building. Similarly, the multi-unit manager can no longer rely on visual inspection or simple physical presence for cost control, but must, instead, interpret numerous interrelated reports in a computer-assisted information rich environment. 
"Float" and cash-flow analysis become workaday tools, rather than just interesting concepts.

Field experience, seminar practicum, cooperative programs, work shops, and any type of training system oriented toward unit operation simply do not address the problems faced at the multi-unit level. A different training strategy is required for senior managers--one that emphaisizes complex problem solving, conceptual, and organization-building skills and that leads to a strategic perspective. This is the focus of a program being launched at the University of Guelp: The Advance Management Program for Hospitality Industry or AMPHI.

The once prevailing management philosophy of "my way or highway" is being supplanted by the view that "employees are our most important resource". 9 Accordingly, most field experience/training focus on the needs of employees which is viewed as the best means of achieving high organization, wide-standards, and retaining qualified personnel. It is hard to appreciate the importance of field experience in hospitality education because such training has not been thoroughly defined within the context of the food and lodging industry. The definition has been said to vary over the years, hence reflecting the opinions of hospitality educators and employers who dominated the industry at various eras.

${ }^{8}$. Daryl Wyckoff and W. Earl Sasser. The Chain Restaurant Industry, (Lexington, MA: D.C. Heath \& Co., 1978), Pp.IXV\&IXVI. 9 Eugene A. Ference. "Toward a Definition of Training", The Cornell Hotel Restaurant Association Quarterly, 1980, P.25. 
Training, field experience during the 1900's to the 1950's for example, can be described as the era of continuity. The prevailing management philosophy of "my way or highway" meant that most of the training given during that period was superficial. At the time labor was readily available, the retention and skills of em-. ployees were accorded low priority.

In the 1960's, focus was on teaching specific skills in response to new modes of technology. This type of experience was purely functional (the intent being simply to teach employees how to use the newly available tools and machinery, while little attention was paid to the development of employees as individuals.

While the labor market conditions began to change, the managers gradually began to review experience more seriously. By the early 1970's, a number of companies realized that offering training opportunities to their employees would help bring about higher productivity, standards and retentions of more employees.

The more employees also realized that turnover was costly. Much of the training in the early 1970's focused on manual skills (how to clean and make a bed for instance). By the mid '70's, management skills were also being taught in numerous company sponsored courses and seminars. Many hospitality corporations instituted supervisory management programs that emphasized human relaitons, communications, motivational theories, leadership styles, and so forth. 
In the 1980's, a number of successful companies strived to close the gap between policies and procedures on paper and the training of human resources in practice. Employees have thus become increasingly aware of the importance of training to their careers, and many anticipate companies to make training activities available as a imatter of course.

Historically, field experience was relegated to the back burner when operations were going smoothly and pushed hurriedly to the forefront when crisis occurred and other strategies proved unsuccessful. 10

Any type of job experience should have short, medium and long-range objectives and should attempt to achieve and maintain specific standards. It should be viewed as a company or an institute-wide process in which technical, managerial, and conceptual skills are cultivated in employees and student interns, respectively. the key to field experience is proper scheduling of training activities based on a systematic analysis-congruent with the overall demands of the industry in concern.

\section{CHANGING PROGRAMS IN HOSPITALITY EDUCATION}

In an effort to meet the changing demands of the hospitality industry today, numerous changes have taken place at all levels. In most recent years, career education has been emphasized. For instance, at the $\mathrm{K}-6$ level, the em- 
phasis is on "Awareness", for grades 7-9 on "Exploration" and from 10-12 on "Preparation". 11 Thus, carefully planned guidance at these various stages is tremendously important.

Many secondary and post-secondary schools are concerned with the placement of students. Placement is a responsibility of institutions with terminal programs. ${ }^{12}$ This implies that follow up studies should be made so that offerings can be altered and improved to meet the changing employment conditions.

Presently, modular scheduling is being used as a means of implementing and improving programs. Numerous schools have experimented on a variety of modular schedules from a few limited courses in the entire program. In too many instances after three or four years, the convention program re-appears. ${ }^{13}$ Theoretically, this concept offer numerous advantages, but in actual practice, there are many problems involved.

Independent study is another concept that is being tried with varying degrees of success. It appears that with good students, properly motivated, and with an instructor who is sincerely interested in this type of instruction, it is a good procedure to follow up. However, this is not the kind of instructional program for all students. Most students are not sufficiently motivated and self-disciplined to make ${ }^{11}$ R.B. Russell, "Changing Programs in Business Education", Business Education Forum, December 1974, p. 23. 12 Ibid, p. 23 13 Ibia. 
good use of the independent study procedure.

On the other hand, the open school and open classroom concepts are receiving increasing emphasis. Students working in related areas, but on a variety of projects, are grouped in the same area. While it is perhaps true that students learn as much from others as from their instructors, careful planning and supervision are necessary to prevent unnecessary confusion. The open school concept is being used on both the elementary and secondary levels. Many new school buildings are constructed so that "classrooms without walls", can be utilized to the fullest extent.

Probably, one of the greatest changes that is taking place in the hospitality education area is the demonstrated interest in the so-called work study programs. Internship in business, on-the-job-training, and work study are the few terms used to describe these programs. With the various changes now taking place at all levels, the industry is apt to take a new turn to meet the demands of its guests and customers.

\section{INITIATING FIELD EXPERIENCE, SEMINAR PRACTICUM AND WORK} STUDY PROGRAMS

It is known that the greater the support from the top, the easier is the task of implementing field experience, seminar practicum and workshop programs. A schedule of 
training and lecture activities that provide all employees, interns and employees with an awareness of their performance standards, the standards of the operation and institution and the activities of fellow employees and interns of the smae operation and institution level will help to foster cooperation rather than completion.

A properly scheduled, continuous and systematic training program will lend an orderly flow to flow field experience function and can actually serve to prevent low productivity and crises from recurring over and over. Systematic time tables should be introduced, identifying dates, time, location, subject, topics, names of trainers, instructors, speakers, facilitators, and participants.

\section{E. SUPPORT BY ACADEMIC ADMINISTRATORS, AND EMPLOYERS FOR FIELD EXPERIENCE, SEMINAR PRACTICUM AND WORK STUDY PROGRAMS}

If any of these management training systems is to be implemented by an institution or organization, it must be supported by management throughout the industry and institutions concerned with the training of potential managers and academic administrators. If, for instance, support from the hospitality management institution Dean, management per- 
sonnel in the industry is lacking department heads who attempt to implement such programs will end up spinning their wheels. An indication of support for such programs top management and administrators can do so by issuing written policy statements that can serve as guidelines for all managers, interns, and employers. When a company or an institution establishes a formal field experience, seminar practicum, cooperative study, and workshop program, a formal field experience policy, employees, interns will automatically visualize the opportunities that are open to them and the expectations they must meet. In addition to the above, such policy helps to inform employees and interns that institutions abd business operations at large attaches a great deal of importance on field experience, seminar practicum, workshops and cooperative study program.

Probably, more important than the form of the written policy is the method in which the program is implemented. Accordingly, every executive officer in the company and assigned educators should be actively involved in these programs from time to time. Their involvement to include meeting with hotel trainees over lunch time, having coffee with employees during field experience session breaks. They should try to find out their problems on the job and make opening and closing remarks at management workshops or become involved in management training and open-forum discussions. 
F. FIELD EXPERIENCE AND THE MODIFIED FORMS OF TRAININGS AIMED AT DEVELOPING THE KNOWLEDGE, SKILLS, AND ATTITUDES OF THE HOSPITALITY INDUSTRY HUMAN RESOURCES

The subject of guest satisfaction in the food and lodging industry has been the topic of most writers in recent years. The performance of interns, employees and management affects guests satisfaction. A satisfied guest not only returns, but recommends an operation to friends and colleagues. Hence, if properly managed field experience and the other modified forms of trainings can be used as vehicles to achieve and maintain standards and guests' satisfaction. Today, employees are paid mainly for the skills they can offer. In the entry level positions, the skills are primarliy technical and manual in nature. the requirements are different when an employee moves to a management position; other demands such as understanding the operation's budget analysis, financial statements, supervision and problem solving, take precedents.

\section{G. PEREORMANCE, GOALS AND MEASUREMENT}

Very little has been done in the past to identify the behavior interns exhibit in order to successfully complete 
a field experience (practicum) course or program. In addition to the above, very little has been done to assist the coordinators in determining the degree of success he or she has attained upon completion of such a course.

The current revolution or emphasis on performance goals/objectives is providing hospitality educators with measureable "ends" which make the selection of means to that end much easier to choose. With performance goals, the intern has direction he/she knows which is expected and how the measurement of proficiency will be determined. ${ }^{14}$ The trainer can also identify whether he/she has been successful in helping the interns reach the objectives and goals identified.

Basically, individuals (interns) are identified as being potential successful managers and educators through completion of a baccalaureate degree in Hospitality Management. However, in order to improve, educators and employed managers have returned to college to complete advanced degrees.

The industry still holds to basic concepts. In addition, there are other areas that should be considered in defining potential success. 
A hospitality manager or academic administrator has the opportunity to function within the environment where his/ her interns will find themselves. The experience needs to be reviewed periodically to keep abreast of the "real business world". 15

\section{H. IMPROVING EMPLOYEES (INTERNS) ATTITUDES}

Many articles have been written on how employees' attitudes can affect productivity. There is a vast pool of literature on the subject of peer group pressure on other employees' attitudes. A complete analysis of employees' attitudes will not be complete without an understanding of the term and its elements. Attitudes are states of minds of individuals towards values, persons, or things. They are constructed from a particular vantage point and have influenced in the formation by such elements as:

1. The physical and environment of the person

2. Past experience, if any

3. Wants and goals

4. The physiological making of the individual.

Attitudes are interrelated with other factors as beliefs and feelings and are based upon information that has been 
made available to the individual. They are important considerations in such related factors as motivation, job satisfaction and morale. ${ }^{16}$

Its analysis will not be complete without mention of the impact of formal or informal groups. It is important to stress that in every organization these two groups are always present. Many studies have shown that informal group is a network of personal and social relations not established or required by formal authority, but arising spontaneously as people associate with one another. ${ }^{17}$ While the formal group conform to the standard goals and objectives of the organization, the informal may not. "The informal group is particularly decisive in social control, rather than conforming to the demands of the organization". ${ }^{18}$ In an environment which informal groups influences other employees' attitudes, productivity is bound to be low. However, most writers advise that mangement need to learn who the informal leaders and subordinates are, and by doing so, learn to work with them to ensure that their influence is furthering the employers' objectives, rather than hindering them.

17 Ibid, p. 25

${ }^{18}$ Ibid. 
Hence, all employees attitudes can be the most critical factor in job performance. All other skills, such as technical and manual, can be taught with relative ease with properly designed training programs, seminar practicum, work study but teaching employees and interns to be self motivated is the hardest thing to do and takes considerable longer. Nevertheless, field experience programs can generate both interest and energy.

I. MEETING THE CHALLENGES OF MODERN BUSINESS AND CUSTOMER DEMANDS

A know educator, Peter Drucker, noted that "the purpose of any business oepration is being able to satisfy the customers". ${ }^{19}$ It becomes more challenging for business operations to meet the challenges of modern business and customer demands concurrentIy.

${ }^{19}$ Wanda L. Stitt. "Office Technology Demands Curriculum Re-evaluation", Business Education Forum, December 1982 , p. 11 . 
Hospitality educators have long been proud of the fact that they teach for and about business, using both vocational and consumer approaches. the majority of hospitality education programs today, remains relatively unchanged from what they were fifteen or twenty or even twenty five years ago. Many will exclaim "they have added computer programming to their curriculum". 20

20 Ibid, p.12. 
This is true and is exactly what should have been done years earlier. Nevertheless, the addition of computer programming and the overall changes in hospitality management and guests demands calls for a critical look at the hospitality education curriculum in its entirety.

A national word processing report conducted by Delta Pi Episolon, stated that "the characteristics of word processing indicate that the educational segment of our economy must come to grips with the needs of business and tomorrow's office works--the school must do more to develop the basic skills of students as well as to provide a background of understanding about information, total systems, and better ways of achieving goals. 21

From all indications, most of the burden falls on the educators who must take on several responsibilities before any changes can be implemented. They must make the effort to read and research constantly in order to remain current with the new technological developments and customer demands in the hospitality industry. These findings then must be communicated effectively via teaching and innovative training methods.

21 Jolene D. Scriver, et al. Summary Report of National study of word Processing Installations in selected Business Organizations, st. Peter, MN: Delta Phi Epsilon, 1981, p. 33. 


\section{J. WHERE TO START}

It is more than obvious that curriculums in the hospitality institutions must change if they are to move forward along with all the new innovations in technology, specifically what can be done and how can they cope? There are several areas which need immediate revolutions.

First, "the purpose of much of the field experience expense is to improve the efficiency of the future hospitality management personnel. Hence field experience (internships) will continue to be a stepping stone for preparation of potential managers and educators to meet up the challenges and demands of the hospitality industry customers.

The first task then to be undertaken as a preliminary effort requires specifying the roles of the interns, employers, employees, and educators. The role of the Department of Hospitality can be derived from the required output associated with the field experience course. This output is the most critical since it becomes the input based upon which the professional curriculum and its associated experiences will be ultimately erected.

The impact of field experience courses can be specified. The educational outcomes should provide the student (interns) with:

1. A definitional framework--terminology analogous to that provided in professional fields such as production, sanitation, supervision, accounting and finance ; 
2. A carefully designed experience in reflective and holistic thinking as it relates to schools or systems of industry thought, and

3. A practical and extended case study of a typical business decision situation whcih produces a range of options compatible with each major system of industry thought, related to the various constituencies affected by that decision (i.e. shareholders, employers, customers, society at large).

At the conclusion of this course, the interns/employees should be in a position to comprehend the fact that such tools as leadership supervision, human relations, production and others are the elements which contribute to customer satisfaction and overall bottom line.

Other variables to be considered include maintenance of the program. This should be provided on a continuous basis through in-service training, monitoring, supervision evaluation, and re-evaluation.

L. THE VIEWS HELD BY HOSPITALITY INDUSTRY PERSONNEL ON THE IMPORTANCE OF FIELD EXPERIENCE AND OTHER REQUIREMENTS

Who is better qualified to evaluate the "products" of hospitality programs than the industry practitioners who hire them? With this idea in mind, the Cornel Quarterly contacted several major hospitality operations for comments d and lodging sahools are doing right and 
wrong in preparing their students for management positions. Their responses were largely positive.

The graduates of hotel school programs are said to be much better qualified persons, experientially as well as academically. The best schools require students to work at least 800 hours in restaurants or hotels, and the hands on experience is so valuable.

On the curriculum: Most schools place more emphasis on food and beverage, but there is more and more need for knowledge of marketing and sales, and rooms managements.

Entry level expectations: Many students expect to go right to the corporate level, and that is not realistic. For corporate, one needs the insight one gets from an operational setting, says Thomas Damewood.

Thomas Perry (Director of Employment), Hyatt, perceives the schools are preparing people better for the realities of the industry than they did five years ago. He cited an example of students not being prepared to work the hours necessary or to work as hard as was expected of them to succeed.

Entry level expectations: It takes a while for them to become supervisors and managers to develop 'people' skills. 
Future requirements: the schools might require Spanish or a second language. He sited an example of how Spanish is needed more and more from Miami to New York to Chicago. On hospitality schools facilities, he observed that some, not all, are missing out a little because they require a Master's or Doctorate degree. He advised that a greater involvement of industry people would give a more up-to-date perspective.

While Gary Gibson, Director of College Relations, Holiday Inns, observed that in general the schools provide a good silid foundation to build upon. He had the same views held by Damewood that a little more emphasis be directed on the hotel side. His views on the above is student's experience tend to be in the food and beverage end of things, coupled with a program heavily slanted toward food and beverage, while losing out on a very important part of our business.

On work requirements: Work experience is a very important part of the educational process. He noted that those who have it can hit the ground running. If there were ways to arrange it, it would be a big plus for students who are required to get work experience to have some supervisory role before graduation. 
Most students have never been put in a position where they have people reporting to them.

On technical training versus management development: In some programs, according to Gibson, the students are too technically oriented and unprepared for a business environment. "They got so tied up in ice carving or whatever, and do not realize we are running a business".

Other participants observed students' shortcomings in interviews. Most do not meet expectations because they have trouble expressing themselves and improvising in an interview.

William Kennedy, District Manager of ARA, observed what schools do best--preparing students for the field experience in terms of hours, commitment, and responsibility required. While the schools that do worst, he observed 'teach numbers'. Schools teach kids accounting and financial statements, but they do not know how to apply it. They will say "I know I have a high food cost. What do I do about it?" That link is missing. On the staff members' involvement in the industry, it is important to stay in touch with operations, and not just at the corporate level, but at the level students will be exposed to upon graduation. 
Information about job opportunities: Schools do not introduce the concept of institutional foodservice as a professional career with a lot of growth opportunities.

These are a few of the views held by hospitality practitioners. The question is how can the institution adjust to eliminate some of these shortcomings.

\section{PROBLEMS INVOLVED IN FIELD PROGRAMS}

There is hardly any subject or topic that is treated that does not have pros and cons. As mentioned, many employers and educators visualize field experience, or training as one of the best ways to prepare future educators and management personnel for the hospitality industry.

On its impact on the industry, we are aware that it will bring about high productivity and develop the skills necessary to meet up guests or customer satisfaction. One important gain from such a program is it gives participants an idea of what their field requires of them. It also helps them to build the confidence necessary to handle the most complex guests'/customers' complaints.

While these advantages can be linked with field experience, there is also the dark side to such programs. Research on topics of related nature have shown that emnlovers still find institutions offering hospitality 
management degrees lacking in this cours. Those that do have no clear insights of its problems.

Very little effort is made to correct the problems that plague the program. Other findings include lack of communication between employee/interns and their educators and managers on the problems that do arise during this period. Many are said to be afraid to say anything for fear of being termed an employee or intern who cannot get along with their supervisors and other employees.

What are some of the problems in communication? Communication system by definition is a necessary vehicle for informing the employees/participants of the policies and objectives of the organization as well as the methods of implementation. 22 To be effective, a communication system must be a completely closed system with a constant feedback to insure understanding, clarity, and reception of the sent message.

The hospitality industry has a language of its own. It is different from that of chemistry or physics, hence employees, participants must demonstrate a reasonable understanding of the language in order to perform their duties effectively. The question arises, how many people who undertake such training programs, have the command of the industry's language?

22 William T. Morgan. "Types of Communication", Hospitality Personnel Management, CBI Publishing Company, Inc., Boston Massachusetts, 1979, pp. 126-127. 
Many just understand the concepts of the industry, but do not know how to apply them. Others, according to the views held by the practitioners, are unable to write. Hence if an instance arises where such employees/interns are sent to perform a certain function, they are likely to be misunderstood in communication. Thus meanings of words have to be clearly defined or explained since most of the employees do not understand the terminologies, due in part that most are foreigners.

Other problems encountered in communication include reliability. In addition to the inability to understand the terms used in the industry, there is the basic inability to read (which does exist with many of the industry workers), dissemination of information can often confuse an issue by not describing what is wanted or what could be done. Thus clear, concise language is needed in communication, not an effort to become flowery or deceptive in what is said. ${ }^{23}$

Finally, lack of trust or preconception. Both are said to contribute to communication problems because the receiver does not believe what the sender is saying.

1. Human Relations Problem

The importance of human relations in any organization can not be overlooked. Many will question the validity of human relations in the lodging and foodservice industry. As a matter of fact, this industry is not automated as most are, thus almost everything is done by hand and its employees are in face-to-face contact with their customers/ 
guests. The whole organization of human relations take a different shape with the various contacts made. There are a number of such contracts. For instance, when workers and customers/guests meet, in the service industry, the relationship adds a new dimension to the pattern of human relations in the lodging and food service. When a customer takes an active part in the business activity, the whole organization must adjust to his behavior. It is true that all service industries have the customers relationship in common, there are neverthe less important structural differences among industries in this group.

Other relationships that might make a structural difference in the human relations in any operation is management employee, management customers/guests, employees/interns, interns/interns and finally educator/interns.

\section{Evaluation Problems}

The next step in the continuing process of field experience training and placement of the interns or employees is evaluation of their performance. A formal evaluation procedure is a recovery element in a well administered training program--it must be realized that evaluation judgements take place even if no formal program is in effect. Employees/interns are judged on how well they perform, supervisors are judged by their workers, and the organization by their customers/guests. 
objective evaluation procedures can be used to assist in identifying those who should be given the grade of "A", "B", "C", or "D" in the case of student interns and those who should be promoted or to help in raising low-performance levels in operating personnel. Evaluation of any type has its faults. People who evaluate the performance of the interns/ employees do not understand the meanings behind evaluation. Many are too lazy to take the time to read the instructions hence judge or evaluate their subordinates without substance. There are a number of ways to evaluate employees/interns, but among the important types which have withstood the test of time and criticism are:

1. Factor check list

2. Graphic rating

3. Forced distribution

4. Management by objective

No matter which of these forms is used, efforts should be made to standardize the evaluation process.

3. Length of the Training Program

Most employees/interns who have taken or under gone training programs in this industry complained about the length of time required to complete the course and its requirements. While many would prefer the time for the course to be shortened, others held the opinion that it should be extended to accomodate areas not covered 
during the period allowed. This problem arises because of the uniqueness of each operation and its leadership. Along these differences there is a central point that has to be reached to resolve this issue of length of the program.

As a practical matter, no employer or educator can teach you how to run a hotel or foodservice operation, so there is no one way to achieve field experience and operating efficiency. Thus educators and employers should strive to confine themselves in implementing the program as best they can and hope to achieve the impact on how well their products manage thereafter. 
III. THE DATA AND THE TREATMENT OF THE DATA 


\section{THE DATA}

The data of this research are of two kinds: Primary data and secondary data. The nature of these two types of data are as follows:

The Primary Data - The responses to questions put to selected two and four year college academic adminstrators constitute one source of primary data. The other type of primary data is the responses to questions put to selected graduates who were enrolled for the field experience practicum course and employers who have been or who are involved in the internship exercise.

The Secondary Data - The normative data and current publication on the field experience semi-practicum, internship in hospitality education will constitute one type of secondary data. The published studies and texts unpublished dissertation and those dealing with field experience constitute another type of secondary data.

\section{A. THE CRITERIA FOR THE ADMISSION OF THE DATA}

Only the revised articles currently published and unpublished dissertations of field experience semi-practicum, internship, the cooperative and the work study programs completed in accordance with the text publishers instructions will be used in this research. 
Only responses from a cross-section of selected hospitality management institution academic administrators with five or more years of experience who indicate and respond to questions put to them by the researcher will be used in this study. It will also include responses from the selected graduates of hospitality management who had participated in the internship/practicum at the time of this survey.

Simarily, only the responses of managers, food and beverage directors and dieticians who have been or are involved in the field experience, semi-practicum internship and practicum will be used in this research.

\section{B. THE RESEARCH METHODOLOGY}

The nature of the data required to complete the survey and prove or refute the hypothesis actually dictates the research methodology. 24

The different kinds of information and data demand two principal approaches and methodologies to deal with each type of data appropriately.

The historical method lends itself to information and data that is written down and retrievable through libraries, direct research of other sources like personal

$\overline{24}$ Paul D. Leedy, Practical Research 2nd Edition, MacMillan Publishing Company, Inc., 1980, P. 86. 
notes and hospitality management institution academic administrator's reports. It is effective in uncovering actions that have occurred and putting them together in a case which can be interpreted for its meanings as a whole. Since this study will not require this type of data on actions that have already transpired that is available in published works, but after the ongoing field experience in hospitality education. The historical method is not tailored to this research requirements.

The descriptive survey method is said to involve observing the population which falls within research parameters and recording what is observed so that it can be analyzed. This analysis will, hopefully, yield fresh insights into the impact of field experience in hospitality education. The population of the research must be carefully chosen, clearly defined and specifically delimited in order to get a precise parameters for ensuring discreteness in the population. Paul D. Leedy cautioned that the data gathered by this method is susceptible to distortion through the introduction of bias into the research design. Naturally, this method as well as the others demand that the data be presented systematically so that valid and accurate conclusions may be drawn from it. The descriptive survey is detailed to this research requirement and will form the source of the primary data. 
The third type of data gathering is the mailing survey. Its advantage include low cost and, if constructed properly, it can be very revealing and comprehensive. It:s disadvantages include the fact that it is relatively inflexible and since the art of administration is always changing hands, educational curriculum are not stable, there is the possibility that a chance at deeper meanings and shades of differences would be lost. The return rate of mailed questionnaires is known to be traditionally low. This could result in loss of potential responses from the survey participants. The researcher felt that the number should be Iimited to not less than three hundred. The notion being that at least one half of the participants will be able to return their questionnaires for analysis. The mail survey method will form the primary source of data for this paper.

Finally, the fourth type of data gathering method is the telephone. Its advantage being that eliminates the possibilities of delay on the part of the participants. Responses are recorded by the researcher. It is know that discrepencies can be corrected within a short period of time. The disadvantages known to be associated with the telephone survey is that most of the information given by the participants are not correctly recorded or are not recorded at a11. It is also known to be very costly. This method will also form the primary source of data for this paper. 


\section{SPECIFIC TREATMENT OF THE DATA FOR EACH SUB-PROBLEM}

1. Sub-Problem One: The first sub-problem is the identification of the impact of field experience in hospitality education.

a. The Data Needed: The data needed to solve sub-problem one is the field experience curriculum specifications, number of hours required, types of field experience, the administrators supervisors, employers, and graduate intern input. The grades and options utilized by the various hospitality institutions, the institutions and their administrators, graduates, interns and employees must meet the criteria established in the methodology section. The data collected will be carefully screened to include only responses of the participants that meet the research methodology requirements.

b. The Location of the Data: The identification data collecting and treatment will be found in materials published by the Journal of Hospitality Education, Business Education Journals, and others will be found at the Florida International University, Florida Atlantic University and the Dade County public Library system. 
The primary data will be found in the experiences, minds and documents of each of the selected administrators, employers, and graduate intern's records.

c. Means of Obtaining the Data: The identification data will be requested of the one hundred and fifty selected hospitality management institution. administrators, one hundred hospitality employers and fifty graduate interns who had once enrolled for the field experience at the time of this research. Prior verbal arrangements for the participants of some hospitality management administrators, employers, and graduates have been made, others are being contacted. Appendix A exhibits the letter requesting participation information and data. A standard devised questionnaire to ensure a uniform survey is attached to the letter requesting the data in the research as Appendix B.

d. The Treatment of the Data: How the Data will be Screened - The completed questionnaire will be used to extract the information and data related to the impact of field experience in hospitality education. The data will be grouped according to the similarities revealed by the selected hospitaltiy management academic curriculums, feedback, monitoring devices and other. 
Each category will be computed to verify the number of participants against responses for each of the twelve questions. Finally, each question will be described in brief and concise words to ease analysis later.

How the item analysis will be made - the data pertaining to sub-problem one will not be analyzed per se. It will, however, form the basis of the information upon which the rest of the research will be founded. The data and information will stress and enumerate the impact of field experience in hospitality education.

How the data will be treated - the impact of field experience in hospitality management education derived from the responses will be interpreted in mathematical terms.

Scoring percentage will be assigned for each time there is a variance or non-variance response between the administrators, employers, and graduate interns based on a one hundred percent or less.

2. Sub-Problem Two: The second sub-problem is analyzing the impact of field experience in hospitality education. 
a. The Data Needed: The data needed to solve subproblem two is the scoring percentage for the eleven items of the hospitality management administrators criterion group their original responses on the impact of field experience in hospitality education, as well as responses from a separate group of employers and graduate interns.

The administrators, graduate interns and employers participating in this research must meet the criteria established in the methodology section.

b. The Location of the Data: The data collecting and treatment to be conducted as part of sub-problem two will be to obtain the responses of the hospitality management administrators criterion groups. The response data from a separate group of hospitality management graduate interns are located in this group. Finally, the response from yet another group of hospitality management supervisors with the power to absorb the field experience participants.

The data will be from their experiences, minds and documents of the administrators, employers, and graduate interns selected by the researcher to be surveyed. The other available information and its normative data is located in the Journal of Hospitality Education, Business Education, published and unpublished thesis and dissertations on field experience, semi-practicum, internship, 
the cooperative and work study programs completed in accordance with the text publisher's instructions which will be used in this research.

c. The Means of Obtaining the Data: The selected hospitality management academic administrators, graduate interns, and employers will be sent a standard devised questionnaire to ensure a uniform survey. The responses will be attached to the research as Appendix $B$.

d. The Treatment of the Data: How the data will be screened - the completed questionnaire will be used to extract the impact of field experience in hospitality education. The data will be grouped according to the similarities revealed in field experience in hospitality education. Other findings and ideas that do not lend themselves to categorization will be included as other findings.

How the analysis will be made - the data relating to sub-problem two will be analyzed in accordance to the administrators, graduate interns and employers opinion as to whether there is a more effective method to analyze the impact of field experience in hospitality education.

How the data will be interpreted - the data will be interpreted as being accurate as presented lacking evidence to the contrary. 


\section{A. THE SOURCE OF THE POPULATION}

The names and addresses of the institutions contacted were drawn in part from a pool of hospitality management colleges and universities in the United States as contained in the 1983/1984 Love Joy Magazine.

While the names and addresses of hospitality operations were drawn at random from another pool of operations in South Florida as contained in the current Hotel Red Book.

Finally, the names and addresses of alumni (students) of the School of Hospitality Management was obtained from the Hotel, Food and Travel Association of Florida International University, Miami and by reference. The names were picked at random from the list of graduates of the classes of 198083. The principal sources may overlook some of the current institutions in the United States which offer courses and degrees in hospitality management, hospitality operations that just opened for business, and finally graduates who did not leave forwarding addresses with the club. These publications and directions used in this research are generally recognized among the hospitality educators and the industry personnel to present a fairly accurate listing of the institutions of hospitality management and hospitality industry in the inited states and cities thereof.

Contact was made by mail with the following hospitality management institutions: Washington state University, Pull- 
man Washington, University of Denver, Cornell University, Ithaca New York, College of Boca Raton, Palm Beach Junior College, Palm Beach; University of Nevada, Nevada; Maimi Dade Community College, Miami; Florida International University, Miami; Broward Community College, Fort Lauderdale; West Valley College, California; Contra Costa College, California; Tuskegee Institute of Technology, Alabama.

Contact was also made by phone and by mail with Burger King Corporation Area Training Supervisor, West Palm Burger King Restaurant interns, Morrison's Cafeteria manager, Palm Beach Founty School Foodservice Director, Sheraton Food and Beverage Director of Boca Raton.

The names of the alumni who participated in the study have been withheld on the request of the participants.

\section{B. THE FORMULATION OF THE SAMPLE}

Relatively few four year institutions maintain an HEl program; consequently, all the four year programs listed as CHRIE members were included in this study. Since the two year programs out number the four year programs ten to one, a different procedure was used to select appropriate two year programs.

NOTE: The analysis of the questionnaire was not done as was previously planned, as this will create additional problems. 
The researchers were selected at random from the first ten of every twenty programs listed in the directories of club membership rosters and employee payroll listings. The sampling is not sequential and alphabetical.

Questionnaires were distributed to ten four year programs and ten two year programs. In addition, ten were mailed to the various restaurant and hotel operations in South Florida; ten were mailed to alumni of Florida International University and Palm Beach Junior college classes of $1982 / 83$ respectively.

\section{THE MEASUREMENT INSTRUMENT}

The questionnaire was designed to measure the impact of field experience in hospitality education and its contribution to the industry at large.

The last question permitted the participants to make informal commentaries about the failure/success of such a program.

This will be the hinge point of the entire study. Though it is not stated in the study, it is implicit in the criteria that the information gathered and the participants surveyed must be a representation of the entire population of the hospitality management industry. 
IV. THE GENERAL PROCEDURE 
As noted throughout the study "field experience" in hospitality education involves two or more homogeneous groups; the educators, alumni, interns, employees, and employers. Surveying the educators of selected institutions yielded a representative sample of that side of administration. The employees of participating hospitality operations in some cases are the owners of the operations and directly or indirectly bear the hiring and financial penalties which arise from field experience. The "participants", as will later be discussed in the "general section", indicated they will be picked from the various hospitality management institutions and hospitality industries around South Florida, while the participating graduates and interns will be selected at random from Florida International University, Miami, graduating class of 1980-82 and others.

Each question was thoroughly thought out and tested in advance. It does not convey professionalism or competence to send an instructor an unplanned type of questionnaire which has no direction and purpose. Each question must in some way focus on extracting information and data relevant to the problems to be addressed. Also needed before beginning the questions was a legitimate introduction which inspired the participant to want to cooperate and be candid. 
This was especially true under sub-problem when success achieved can be distorted and self serving.

A questionnaire was constructed which the researcher mailed to the survey participants. The response to each question by the participants were immediately typed in as they were received, but analysis was delayed until twenty of the questionnaires were returned. A sample of the survey questionnaire sheet is attached in Appendix B.

The first item on the questionnaire is the name of the institution. This item was needed to help identify possible sources of managerial and administrative opinion as they spread through the industry. It can also help in relating how educators, administrators, employers, owners, employees and interns feel about field experience in the hospitality industry and how the employers view the "products" of hospitality management when they appear before them for interviews and thereafter.

The second item contained in the questionnaire is the Rank of the Administrator. In his article on the problems in Distribution and Transportation, stuart Mann reveales that there are a variety of positions occupied by people calling the shots in both the commissaries and foodservice industry, and this is also true of the institutions and operations surveyed in this paper. 25

\footnotetext{
25 Stuart H. Mann, The Problems of Distribution and Transportation in Centralized Food Production Facility, The Journal of Hospitality Education, Vol. 1, July 1976.
} 
A pattern of corporation executives and administrative attitudes toward field experience or functioning of the program and its out-put may have a direct effect on the success or failure of the participants initiatives to view the impact of field experience in hospitality industry objectively.

The duty title can also reveal the span of control of the individual participant, his powerbase, or position in the entire organization or institution. This might be especially significant and have a great bearing on his effectiveness in dealing with the subject or his willingness to advocate for the program. Also by using the rank, I had to cross check whether I was staying within the definition of the Type of Data Source desired as noted previously.

Included in the questionnaire is the duration in this type of position: this will give the researcher an idea of the length of time the participant has occupied a position of this type in the field of hospitality management. The item was not used necessarily as a criteria for eliminating a participant based on too short or too long a time, but it was a very important factor to consider in the validity and reliability of the importance of field experience in the hospitality industry. It might also have a bearing on the second sub problem in that it will be a factor to consider in measuring the relative success or failure of any given management or administrative opinion, since a more experienced personnel may have observed the impact of field 
experience over a longer trial period. This was always the possibility of immediate documented improvements, and were also long term techniques which matured, changed and became more effective, or those that just proved to re-adjust with change in time. Also techniques and curriculum are due to change with the demands of the work place/ institution. This could be an advantage of the fresh approach of an experienced administrator/manager. All of those helped make the date more complex, but to ignore them might have made the data lack the vital elements which could cause a completely erroneous picture of the situation.

The name is the next item following the duty title. It gives me the opportunity to contact the rightful personnel in case there were any questions to be resolved concerning the questionnaire. I was able to call the participants person-to-person, thus reduced the cost of telephone bills when the participants could not be reached.

The next two items, the phone numbers and addresses are also self explanatory and mostly served to identify the location of the operations and to make any necessary follow up or further data collection.

The term "study" was used interchangeably with "thesis" to eliminate the notion that management personnel are likeIy to evade the survey for fear of saying something that will jeopardize their positions and companies. 
Finally, I briefly stated the pre-prepared description of the subject I was studying so that each participant understood what information was desired. This also applied to each of the questions contained in the questionnaire.

The following are the questions asked on the interview and the initial rationale for their inclusion: 
9760 S.W. 184th Street \#12 D

Miami, Florida 33157

December 1, 1983

Dear Sir/Madam:

Enclosed please find a questionnaire mailed to you in the hope that you will be able to assist me in obtaining information and data for a research paper on "The Impact of Field Experience in Hospitaltiy Education".

Your involvement as a participant in this research will be appreciated if you take the time to respond to the twelve questions contained in the questionnaire, and return it in the enclosed envelope.

I appreciate your cooperation and look forward to your early reply since $I$ am attempting to graduate in May, 1984. Yours farthulix,

$\angle$ Peter okon Aggomi

POA/pp

Encl: 
NAME OF INSTITUTION:

RANK :

DURATION IN THIS TYPE OF POSITION:

NAME :

PHONE NUMBER AND ADDRESS:

1.A. Students in our Hospitality Management Program are required to complete some kind of field experience.

$$
\text { Yes }
$$

No

B. What type of field experience, please circle one.
a. On the job training
b. Seminars
c. Practicum or internship
d. Work study program
e. Cooperative study

2.A. To satisfy a field experience requirement, a student must complete hours on the job.
a. 100-160 hours
b. 161-220 hours
c. 221-280 hours
d. 281 and above

B. To satisfy a field experience requirement, the student must:
a. Work without pay
b. Work with pay
c. Other (please specify)

3. The supervision of the students enrolled for field experience is done by
a. faculty members
b. employers
c. jointly by $a$ and $b$
d. others
e. jointly by $a$ and $d$ 
4. Please rank on a scale of 1 to 4 , the importance of those five elements in your curriculum.

Major or professional courses Professionally related field experience Non-major technical courses Science

5. Our institution waives the field experience requirement for a position that has no parallel in the hsopitality industry.

6. Please mark any job positions which would be accepted for the field experience requirement.
a. Banquet Manager
b. Maintenance engineer
c. Dietary personnel
d. Stock clerk
e. Bus boy
f. First cook
g. Real estate cook
h. Night auditor
i. Concession stand operator
j. Host or hostess

7. What are the core curriculum requirements for
a. Associate in Science
b. Bachelor's Degree
c. Master's Degree

in Hospitality Management?

8. How is the field experience requirement monitored by your institution? Please name the methods employed. 
9. Is there a grade option for the field experience requirement?

10. In your opinion, is it justifiable to say that field experience and other modified experiences such as seminar, practicum, the cooperative and the work study programs will not play an important role of closer alliance between the academic and the hospitality industry?

11. Is it possible to offer courses in field experience which will enhance the professionally oriented course work, while educators, academic administrators and employers strive to design a common curriculum that is needed to meet the educational and the industry demands and goals? Please comment.

12. What are some of the problems that face the interns during the field experience period? 
APPENDIX B

QUESTIONNAIRE

NAME OF INSTILUTION: F.I.U.

RANK: Assistant Professor

DURATION IN THIS TYPE OF POSITIUN: 3 yearS

NAME: Steven V. Moll

PHONE NUMBER AND ADDRESS: 6500, Kendale Lakes Dr. 554-2591

1.A. Students in our Hospitality Management Program are required to complete some kind of field experience.

Yes

No

B. What type of field experience, please circle one.

a. On the job training

b. Seminars

c. Practicum or internship $\mathrm{x}$

d. Work study program

e. Cooperative study

2.A. To satisfy a field experience requirement, a student must complete hours on the job.
a. 100-160 hours
b. 161-220 hours
c. 221-280 hours
d. $28 I$ and above $x$

B. To satisfy a field experience requirement, the student must:
a. Work without pay
b. Work with pay
c. Other (please specify) $x$ with or without- depending upon the company

3. The supervision of the students enrolled for field experience is done by
a. faculty members $x$
b. employers
c. jointly by $a$ and $b$
d. others
e. jointly by a and d 
4. Please rank on a scale of 1 to 4 , the importance. of those five elements in your curriculum.

2 Major or professional courses
1 Professionally related field experience
4 Non-major technical courses
5 Science

5. Our institution waives the field experience requirement for a position that has no parallel in the hospitality industry.

Yes

6. Please mark any job positions which would be accepted for the field experience requirement.
a. Banquet Manager $x$
b. Maintenance engineer
c. Dietary personnel
d. Stock clerk
e. Bus boy
f. First cook
g. Real estate cook
h. Night auditor
i. Concession stand operator
j. Host or hostess

7. What are the core curriculum requirements for
a. Associate in Science 60 sem. hours
b. Bachelor's degree $123 \mathrm{sem}$. hours
c. Master's degree $x \quad 33$ grad. sem.hours

in Hospitality Management?

8 How is the field experience requirement monitored by your institution?. Please name the methods employed.

Internship monitored by a professor 
9. Is there a grade option for the field experience requirement?

No Pass/Fail

Iv. In your opinion, is it justifiable to say that field experience and other modified experiences such as seminar, practicum, the cooperative and the work study programs will not play an important role of closer alliance between the academic and the hospitality industry?

No, it will always play an important role.

11. Is it possible to offer courses in field experience which will enhance the professionally oriented course work, while educators, academic administrators and employers strive to design a common curriculum that is needed to meet the educational and the industry's demands and goals? Please comment.

Yes.

12. What are some of the problems that face the interns during the field experience period?

Lack of attention by industry supervisors. 
NAME OF INSTITUTION: University of Denver

RANK: Professor

DURATION IN THIS TYPE OF POSITION: 3 yearS

NAME: V. Chandrasckar

PHONE NUMBER AND ADDRESS: University of Denver, Denver $303-8,71-2000$

1.A. Students in our Hospitality Management Program are required to complete some kind of field experience.

Yes $\mathrm{X}$ No

B. What type of field experience, please circle one.
a. On the job training $x$
b. Seminars
c. Practicum or internship
d. Work study program
e. Cooperative study

2.A. To satisfy a field experience requirement, a student must complete 200 hours on the job.
a. 100-160 hours
b. 161-220 hours
c. 221-280 hours
d. 281 and above
$\mathrm{X}$

B. To satisfy a field experience requirement, the student must:
a. Work without pay
b. Work with pay $X$
c. Other (please specify)

3. The supervision of the students enrolled for field experience is done by
a. faculty members
b. employers
c. jointly by $a$ and $b x$ univ. Grad:
d. others
e. jointly by a and $d$ 
4. Please rank on a scale of 1 to 4 , the importance of those five elements in your curriculum.

5 Major or professional courses Business

3 Prófessionally related field experience Food

Service

2 Non-major technical courses

4 Science $\quad$ ।

5. Our institution waives the field experience requirement for a position that has no parallel in the hospitality industry.

6. Please mark any job positions which would be accepted for the field experience requirement.
a. Banquet Manager
b. Maintenance engineer
c. Dietary personnel
d. Stock clerk
e. Bus boy
f. First cook
g. Real estate cook
h. Night auditor $X$
i. Concession stand operator N/A
j. Host or hostess

7. What are the core curriculum requirements for
a. Associate in Science
b. Bachelor's degree $X$
c. Master's degree $X$

in Hospitality Management?

8 How is the field experience requirement monitored by your institution?. Please name the wethods employed.

Employer/instiution Program Director 
9. Is there a grade option for the field experience requirement?

$$
\text { No }
$$

10. In your opinion, is it justifiable to say that field experience and other modified experiences such as seminar, practiaum, the cooperative and the work study programs will ot play an important role of closer alliance between the academic and the hospitality industry?

No it is not, because any education without experience is as bad as a farmer without equipment.

11. Is it possible to offer courses in field experience which will enhance the professionally oriented course work, while educators, academic administrators and employers strive to design a common curriculum that is needed to meet the educational and the industry deman's and goals? Please comment.

\section{Management}

12. What are some of the problems that face the interns during the field experience period?

No problems at the present 
NAME OF INSTITUTION: Washington State University

RANK: Director of Hotel

DURATION IN THIS TYPE OF POSITION: 9 yearS

NAME: Terry Umbreit

PHONE NUMBER AND ADDRESS: Washington State, Seattle

$$
509-335-5766
$$

1.A. Students in our Hospitality Management Program are required to complete some kind of field experience.

Yes $\mathrm{x}$ No

B. What type of field experience, please circle one.
a. On the job training $x$
b. Seminars
c. Practicum or internship
d. Work study program
e. Cooperative study

2.A. To satisfy a field experience requirement, a student must complete 1000 hours on the job.
a. 100-160 hours
b. 161-220 hours
c. 221-280 hours
a. Work without pay
b. Work with pay $X$
c. Other (please specify)

d. 281 and above $X 1000$ hours done during summer

prior to registering for a $2 \mathrm{hr}$. credi

B. To satisfy a field experience requirement, the student must:

3. The supervision of the students enrolled for field experience is done by
a. faculty members
b. employers
c. jointly by $a$ and $b$ x
d. others
e. jointly by a and d 
4. Please rank on a scale of 1 to 4 , the importance of those five elements in your curriculum.

1. Major or professional courses

3 Professionally related field experience

4 Non-major technical courses

2 Science

5. Our institution waives the field experience requirement for a position that has no parallel in the hospitality industry.

No

6. Please mark any job positions which would be accepted for the field experience requirement.
a. Banquet Manager $\mathrm{X}$
b. Maintenance engineer
c. Dietary personnel
d. Stock clerk
e. Bus boy
f. First cook
g. Real estate cook
h. Night auditor $x$
i. Concession stand operator
j. Host or hostess

7. What are the core curriculum requirements for
a. Associate in Science
b. Bachelor's degree
c. Master's degree
Not Specific

in Hospitality Management?

8 How is the field experience requirement monitored by your institution?. Please name the methods employed.

After the student completes 1000 hrs. in the field he then registers for a 2 credit hr course which

is a pass/fail situation. 
9. Is there a grade option for the field experience requirement?

Pass/Fail

10. In your opinion, is it justifiable to say that field experience and other modified experiences such as seminar, practictum, the cooperative and the work study programs will ot play an important role of closer alliance between the academic and the hospitality industry?

No

11. Is it possible to offer courses in fid experience which will enhance the professionally oriented course work, while educators, academic administrators and employers strive to design a common curriculum that is needed to meet the educational and the industry deman's and goals? Please comment.

Yes

12. What are some of the problems that face the interns during the field experience period?

Sonetimes business gets slow and the students are laid off, this sets frustration in the whole ball game. 
NAME OF INSTITUTION: Florida State Univ., Tallahassee

RANK: Coordinator Internship Program

DURATION IN THIS TYPE OF POSITION: 4 years

NAME: David Pavic

PHONE NUMBER AND ADDRESS: F.S. U., Tallahassee $904-844-4787$

1.A. Students in our Hospitality Management Program are required to complete some kind of field experience.

Yes $\mathrm{X}$ No

B. What type of field experience, please circle one.
a. On the job training
b. Seminars
c. Practicum or internship
d. Work study program
e. Cooperative study
f. Management Training $X$

2.A. To satisfy a field experience requirement, a student must complete hours on the job.
a. 100-160 hours
b. 161-220 hours
c. 221-280 hours
d. 281 and above

$\mathrm{X}$

B. To satisfy a field experience requirement, the student must:
a. Work without pay
b. Work with pay
c. Other (please specify)

3. The supervision of the students enrolled for field experience is done by
a. faculty members $x$
b. employers
c. jointly by $a$ and $b$
d. others
e. jointly by a and $d$ 
4. Please rank on a scale of 1 to 4 , the impurtance of those five elements in your curriculum.

1 Major or professional courses
2 Professionally related field experience
4 Non-major technical courses
3 Science

5. Our institution waives the field experience requirement for a position that has no parallel in the hospitality industry.

No

6. Please mark any job positions which would be accepted for the field experience requirement.



7. What are the core curriculum requirements for
a. Associate in Science
b. Bachelor's degree $X$
c. Master's degree

in Hospitality Management?

How is the field experience requirement monitored by your institution?. Please name the methods employed.

coordinator/management of the operation which the intern is involved. 
9. Is there a grade option for the field experience requirsment?

$$
\text { Yes Pass/Fail }
$$

10. In your opinion, is it justifiable to say that field experience and other modified experiences such as seminar, practiclum, the cooperative and the work study programs will not play an important role of closer alliance between the academic and the hospitality industry?

No, definitely it is critical. This should also involve the management and institutional team. The student should be involved in decision making process.

11. Is it possible to offer courses in field experience which will enhance the professionally oriented course work, while educators, academic administrators and employers strive to design a common curriculum that is needed to meet the educational and the industry deman's and goals? Please comment.

Yes

12. What are some of the problems that face the interns during the field experience period?

Finding jobs for the interns by students themselves since the institution does not provide such luxury. 
NAME OF INSTITUIION: University of Nevada, School of Hotel Administration

RANK: Professor

DURATION IN THIS TYPE OF POSITION: 15 years

NAME: Dr. Basile

PHONE NUMBER AND ADDRESS: $1-702-739-3230$

1.A. Students in our Hospitality Management Program are required to complete some kind of field experience.

Yes $\quad$ No

B. What type of field experience, please circle one.
a. On the job training
b. Seminars
c. Practicum or internship $\mathrm{X}$
d. Work study program
e. Cooperative study

2.A. To satisfy a field experience requirement, a student must complete hours on the job.
a. 100-160 hours
b. 161-220 hours
c. 221-280 hours
d. 281 and above
$\mathrm{X}$

B. To satisfy a field experience requirement, the student must:

a. Work without pay $x$ up to 400 hrs. requirement

b. Work with pay $x$ up to 800 hrs.

c. Other (please specify)

3. The supervision of the students enrolled for field experience is done by
a. faculty members
b. employers
c. jointly by a and $b \quad x$
d. others
e. jointly by $a$ and $d$ 
4. Please rank on a scale of 1 to 4 , the importance. of those five elements in your curriculum.

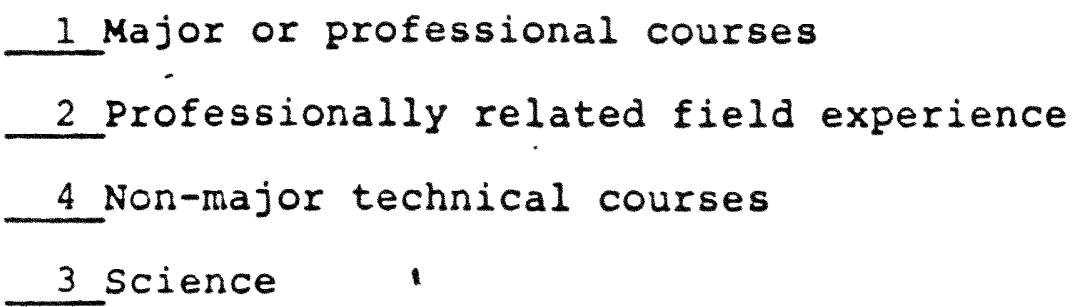

5. Our institution waives the field experience requirement for a position that has no parallel in the hospitality industry.

No

6. Please mark any job positions which would be accepted for the field experience requirement.
a. Banquet Manager $\mathrm{X}$
b. Maintenance engineer
c. Dietary personnel
d. Stock clerk
e. Bus boy
f. XIXz cook
$\mathrm{X}$
g. Real estate cook
h. Night auditor $X$
i. Concession stand operator
$j$. Host or hostess $x$

7. What are the core curriculum requirements for
a. Associate in Science
b. Bachelor's degree
c. Master's degree
All depenas on what you have when you com into school

in Hospitality Management?

8 How is the field experience requirement monitored by your institution?. Please name the methods employed.

By both the faculty \& supervisor on the job 
9. Is there a grade option for the field experience requirement?

$$
\text { No Pass/Fail situation }
$$

10. In your opinion, is it justifiable to say that field experience and other modified experiences such as seminar, practicum, the cooperative and the work study programs will not play an important role of closer alliance between the academic and the hospitality industry?

No, certainly experience plays an important part

11. Is it possible to offer courses in fiend experience which will enhance the professionally oriented course work, while educators, academic administrators and employers strive to design a common curriculum that is needed to meet the educational and the industry deman's and goals? please comment.

Yes

12. What are some of the problems that face the interns during the field experience period?

No problem, so far. 


\section{APPENDIX B}

QUESTIONNAIRE

NAME OF INSTITUTION: Cornell University

RANK: Special Assistant to the Dean

DURATION IN THIS TYPE OF POSITION: 6 months

NAME : Fred Antil

PHONE NUMBER AND ADDRESS:

1.A. Students in our Hospitality Management Program are required to complete some kind of field experience.

Yes $\mathrm{X}$ No

B. What type of field experience, please circle one.
a. On the job training $x$
b. Seminars
c. Practicum or internship
d. Work study program
e. Cooperative study

2.A. To satisfy a field experience requirement, a student must complete hours on the job.
a. 100-160 hours
b. 161-220 hours
c. 221-280 hours
d. 281 and above $\times 6$ months

B. To satisfy a field experience requicement, the student must:
a. Work without pay
b. Work with pay $X$
c. Other (please specify)

3. The supervision of the students enrolled for field experience is done by
a. faculty members
b. employers
c. jointly by $a$ and $b x$
d. others
e. jointly by a and $d$ 
4. Please rank on a scale of 1 to 4 , the importance of those five elements in your curriculum.

1 Major or professional courses

3 Professionally related field experience

4 Non-major technical courses

2 science

5. Our institution waives the field experience requirement for a position that has no parallel in the hospitality industry.

No

6. Please mark any job positions which would be accepted for the field experience requirement.
a. Banquet Manager $\mathrm{X}$
b. Maintenance engineer
c. Dietary personnel
d. Stock clerk
e. Bus boy
f. First cook
g. Real estate cook
h. Night auditor $x$
i. Concession stand operator
j. Host or hostess

7. What are the core curriculum requirements for
a. Associate in Science
b. Bachelor's degree
c. Master's degree

in Hospitality Management?

How is the field experience requirement monitored by your institution?. Please name the methods employed.

By the employer and then the students have to write three reports which are graded - a total of 12 hours. 
9. Is there a grade option for the field experience requi ement?

Yes A thru $F$

10. In your opinion, is it justifiable to say that field experience and other modified experiences such as seminar, practicum, the cooperative and the work study programs will not play an important role of closer alliance between the academic and the hospitality industry?

Absolutely not

11. Is it possible to offer courses in field experience which will enhance the professionally oriented course work, while educators, academic administrators and employers strive to design a common curriculum that is needed to meet the educational and the industry deman's and goals? please comment.

Yes

12. What are some of the problems that face the interns during the field experience period?

Some of the problems encountered are trying to match the students with the property and most of the time trying to make sure they are involved in management functions even though they don't have to make decisions. 
NALE OF INSTITUTION: Biscayne College

RANK: Professor \& Chairman, Division of Travel/Tourism

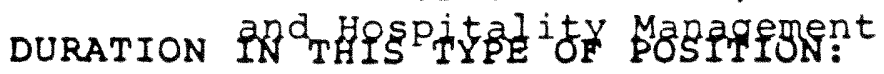

NAME: John H. Bradley

PHONE NUMBER AND ADDRESS: 1600 N.W. 32 Ave. Miami, 33054 $625-6000$

1.A. Students in our Hospitality Management Program are required to complete some kind of field experience. Yes $\quad$ No

B. What type of field experience, please circle one.
a. On the job training
b. Seminars
c. Practicum or internship $\mathrm{X}$
d. Work study program
e. Cooperative study

2.A. To satisfy a field experience requirement, a student must complete hours on the job.
a. 100-160 hours
b. 161-220 hours
c. 221-280 hours
d. 281 and above
$\mathrm{X}$

B. To satisfy a field experience requirement, the student must:
a. Work without pay $x$
b. Work with pay
c. Other (please specify)

3. The supervision of the students enrolled for field experience is done by
a. faculty members
b. employers
c. jointly by a and $b$ $x$
d. others
e. jointly by a and d 
4. Please rank on a scale of 1 to 4 , the importance of those five elements in your curriculum.

1 Major or professional courses
2 Professionally related field experience
3 Non-major technical courses
4 Science

5. Our institution waives the field experience requirement for a position that has no parallel in the hospitality industry.

No

6. Please mark any job positions which would be accepted for the field experience requirement.
a. Banquet Manager $x$
b. Maintenance engineer
c. Dietary personnel
d. Stock clerk
e. Bus boy
f. First cook
g. Real estate cook
h. Night auditor $x$
i. Concession stand operator
j. Host or hostess $x$

7. What are the core curriculum requirements for
a. Associate in Science
b. Bachelor's degree $x$
c. Master's degree

in Hospitality Management?

8 How is the field experience requirement monitored by your institution?. Please name the methods employed.

special forms are provided which must be filled out by employer. Included must be job description and assessment. 
9. Is there a grade option for the field experience requirement?

Yes

10. In your opinion, is it justifiable to say that field experience and other modified experiences such as seminar, practicum, the cooperative and the work study programs will fot play an important role of closer alliance between the academic and the hospitality industry?

Field Experience is indispensible

11. Is it possible to offer courses in fieid experience which will enhance the professionally oriented course work, while educators, academic administrators and employers strive to design a common curriculum that is needed to meet the educational and the industry deman's and goals? Please comment.

We are setting up a catering department which will handle all social functions and meetings on the campus. Students will receive course credit.

12. What are some of the problems that face the interns during the field experience period?

There seem to be no major problems. Age (youth) can be a barrier. 
NAME OF INSTITUTION: College of Boca Raton, Boca Raton, Fla. RANK: Coordinator Hospitality Programs

DURATION IN THIS TYPE OF POSITION:

NAME: R. Bartholemeu

PHONE NUMBER AND ADDRESS: College of BOCa Raton

1.A. Students in our Hospitality Management Program are required to complete some kind of field experience. Yes $\quad$ No

B. What type of field experience, please circle one.
a. On the job training
b. Seminars
c. Practicum or internship $x$
d. Work study program
e. Cooperative study

2.A. To satisfy a field experience requirement, a student must complete hours on the job.
a. 100-160 hours
b. 161-220 hours
$\mathrm{X}$
c. 221-280 hours
d. 281 and above

B. To satisfy a field experience requirement, the student must:
a. Work without pay
b. Work with pay
c. Other (please specify) A\&B

3. The supervision of the students enrolled for field experience is done by
a. faculty members
b. employers $X$
c. jointly by $a$ and $b$
d. others
e. jointly by a and $d$ 
4. Please rank on a scale of 1 to 4 , the importance of those five elements in your curriculum.

$$
\begin{aligned}
& 1 \text { Major or professional courses } \\
& 2 \text { Professionally related field experience } \\
& 4 \text { Non-major technical courses } \\
& 3 \text { Science }
\end{aligned}
$$

5. Our institution waives the field experience requirement for a position that has no parallel in the hospitality industry.

No

6. Please mark any job positions which would be accepted for the field experience requirement.
a. Banquet Manager $\mathrm{X}$
b. Maintenance engineer
c. Dietary personnel $\mathrm{X}$
d. Stock clerk
e. Bus boy $\mathrm{X}$
f. First cook $X$
g. Real estate cook
h. Night auditor $X$
i. Concession stand operator $X$
j. Host or hostess

7. What are the core curriculum requirements for
a. Associate in Science
b. Bachelor's degree
c. Master's degree

in Hospitality Management?
$X$ General Eduation Re-

$X$ quirements.

Introduction to Hospi. tality Management. Housekeeping Managemes Marketing/Sales Promotion.

How is the field experience requirement monitored by your institution?. Please name the methods employed.

Weekly reports are graded. The reports cover the various job assignments a student has done. 
9. Is there a grade option for the field experience requirement?

Grade A thru Fail

10. In your opinion, is it justifiable to say that field experience and other modified experiences such as seminar, practicum, the cooperative and the work study programs will oot play an important role of closer alliance between the academic and the hospitality industry?

No, this industry needs people with experience and devotion to work. Most courses are geared in that direction.

11. Is it possible to offer courses in field experience which will enhance the professionally oriented course work, while educators, academic administrators and employers strive to design a common curriculum that is needed to meet the educational and the industry deman's and goals? Please comment.

Yes

12. What are some of the problems that face the interns during the field experience period?

- Students bargaining for grades they do not desire.

- Placing the students in what they feel they need most.

- Communication with peers and management team. 


\section{QUESTIONNAIRE}

NAME OF INSTITUTION: Sheraton BOCa Raton

RANK: Director of Food/Beverage

DURATION IN THIS TYPE OF POSITION: 1 year

NAME: Vincent Desantis

PHONE NUMBER AND ADDRESS: 2000 NW 19th St. BOca Raton, Fl. $305-368-5282$

1.A. Students in our Hospitality Management Program are required to complete some kind of field experience. Yes $\quad \mathrm{X}$ No

B. What type of field experience, please circle one.
a. On the job training $\mathrm{X}$
b. Seminars
c. Practicum or internship
d. Work study program
e. Cooperative study

2.A. To satisfy a field experience requirement, a student must complete hours on the job.
a. 100-160 hours
b. 161-220 hours
c. 221-280 hours
d. 281 and above

B. To satisfy a field experience requirement, the student must:
a. Work without pay
b. Work with pay
c. Other (please specify)

3. The supervision of the students enrolled for field experience is done by
a. faculty members
b. employers
c. jointly by $a$ and $b$
d. others
e. jointly by a and $d$ 
4. Pl ase rank on a scale of 1 to 4, the importance of those five elements in your curriculum.

Major or professional courses
Professionally related field experience
Non-major technical courses
Science N/A

5. Our institution waives the field experience requirement for a position that has no parallel in the hospitality'industry.

No

6. Please mark any job positions which would be accepted for the field experience requirement.
a. Banquet Manager
b. Maintenance engineer
c. Dietary personnel
d. Stock clerk
e. Bus boy
f. rixet cook
g. Real estate cook
h. Night auditor
i. Concession stand operator
$j$. Host or hostess $\mathrm{X}$

7. What are the core curriculum requirements for
a. Associate in Science
b. Bachelor's degree
c. Master's degree

in Hospitality Management?

8 How is the field experience requirement monitored by your institution?. Please name the methods employed.

By form of a check list stating what has-been accomplished in each position. 
9. Is there a grade option for the field experience requirement?

Yes

10. In your opinion, is it justifiable to say that field experience and other modified experiences such as seminar, practiclum, the cooperative and the work study programs will not play an important role of closer alliance between the academic and the hospitality industry?

No field experience is extremely important.

11. Is it possible to offer courses in field experience which will enhance the professionally oriented course work, while educators, academic administrators and employers strive to design a common curriculum that is needed to meet the educational and the industry deman's and goals? please comment.

Yes, field experience is extremely important to the development of entry level management.

12. What are some of the problems that face the interns during the field experience period?

1. Adjustment to the realization that the hospitality business is not always as it is portrayed in books.

2. Adjustment to the hours of work and pressures. 
NAME OF INSTITUTION: Palm Beach Junior College, Lake worth, Fl. RANK: Coordinator Practicum

DURATION IN THIS TYPE OF POSITION: 10 years

NAME: Ji Rivia

PHONE NUMBER AND ADDRESS: Palm Beach Junior College, Lake worth $439-8000$

1.A. Students in our Hospitality Management Program are required to complete some kind of field experience. Yes No

B. What type of field experience, please circle one.
a. On the job training
b. Seminars
c. Practicum or internship $x$
d. Work study program
e. Cooperative study

2.A. To satisfy a field experience requirement, a student must complete hours on the job.
a. 100-160 hours
$\mathrm{X}$
b. 161-220 hours
c. 221-280 hours
d. 281 and above

B. To satisfy a field experience requirement, the student must:
a. Work without pay $\mathrm{X}$
b. Work with pay
c. Other (please specify)

3. The supervision of the students enrolled for field experience is done by
a. faculty members
b. employers
c. jointly by $a$ and $b$
d. others
e. jointly by a and $d$ 
4. Please rank on a scale of 1 to 4, the importance of those five elements in your curriculum.

1 Major or professional courses

2 Professionally related field experience

4 Non-major technical courses

3 Science $\quad$,

5. Our institution waives the field experience requirement for a position that has no parallel in the hospitality industry.

6. Please mark any job positions which would be accepted for the field experience requirement.
a. Banquet Manager $\mathrm{X}$
b. Maintenance engineer
c. Dietary personnel $\mathrm{X}$
d. Stock clerk
e. Bus boy
$\mathrm{X}$
f. First cook
g. Real estate cook
h. Night auditor $\mathrm{X}$
i. Concession stand operator
j. Host or hostess

7. What are the core curriculum requirements for
a. Associate in Science $x$-Introduction to Hotel/
b. Bachelor's degree Motel Management
c. Master's degree
- Quantity Food Preparation
- Front office Procedures
- Housekeeping
- General Education Require-
ments.

in Hospitality Management?

8 How is the field experience requirement monitored by your institution?. Please name the methods employed.

By the coordinator of practicum on a one to one basis. Discussion of that has been learnt and deficiencies.

Class work and examination. 
9. Is there a grade option for the field experience requireme t?

Grade A through $\mathrm{F}$

10. In your opinion, is it justifiable to say that field experience and other modified experiences such as seminar, practicum, the cooperative and the work study programs will not play an-important role of closer alliance between the academic and the hospitality industry?

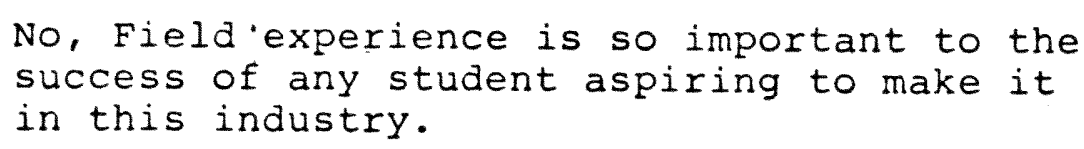

11. Is it possible to offer courses in field experience which will enhance the professionally oriented course work, while educators, academic administrators and employers strive to design a common curriculur. that is needed to meet the educational and the industry deman's and goals? please comment.

Yes

12. What are some of the problems that face the interns during the field experience period?

- Finding companies that are willing to offer these students jobs in areas that the students feel the need of experience most.

- Employers not willing to pay the students for what they are worth. 


\section{QUESTIONNAIRE}

NAME OF INSTItUTION: Miami Dade Community College, 300 NE 2 Ave. RANK: Associate Lecture Mia. Fla.

DURATION IN THIS TYPE OF POSITIUN: 7 years

NAME: $\quad$ Phillip Williams

PHONE NUMBER AND ADDRESS: 300 N.E. 2nd Ave., Mia, Fl. $577-6790$

1.A. Students in our Hospitality Management Program are required to complete some kind of field experience.

Yes $\quad$ No

B. What type of field experience, please circle one.
a. On the job training
b. Seminars
c. Practicum or internship $\mathrm{x}$
d. Work study program
e. Cooperative study

2.A. To satisfy a field experience requirement, a student must complete hours on the job.
a. 100-160 hours
b. 161-220 hours
c. 221-280 hours
d. 281 and above
$\mathrm{X}$

B. To satisfy a field experience requirement, the student must:
a. Work without pay $x$
b. Work with pay
c. Other (please specify)

3. The supervision of the students enrolled for field experience is done by
a. faculty members
b. employers
c. jointly by $a$ and $b$
d. others
e. jointly by a and d 
4. Please rank on a scale of 1 to 4 , the importance of those five elements in your curriculum.

1 Major or professional courses

2 Professionally related field experience

Balance 4 Non-major technical courses

3 Science $\quad$ t

5. Our institution waives the field experience requirement for a position that has no parallel in the hospitality industry.

No

6. Please mark any job positions which would be accepted for the field experience requirement.
a. Banquet Manager
b. Maintenance engineer
c. Dietary personnel
d. Stock clerk
e. Bus boy $\mathrm{X}$
f. First cook $X$
g. Real estate cook
h. Night auditor $x$
i. Concession stand operator
j. Host or hostess $X$

7. What are the core curriculum requirements for
a. Associate in Science $x$ Total credit 6 hrs.
b. Bachelor's degree
c. Master's degree

in Hospitality Management?

8 How is the field experience requirement monitored by your institution?. Please name the methods employed.

Monitored by supervisor and followed by class hour once a week and closely checked by the instructor who takes care of the internship. 
9. Is there a grade option for the field experience requirement?

Yes

10. In your opinion, is it justifiable to say that field experience and other modified experiences such as seminar, practicum, the cooperative and the work study programs will not play an important role of closer alliance between the academic and the hospitality industry?

No

11. Is it possible to offer courses in field experience which will enhance the professionally oriented course work, while educators, academic administrators and employers strive to design a common curriculum that is needed to meet the educational and the industry deman's and goals? please comment.

Yes, industry should try to work more closely with the school to enable them to know what their needs are.

12. What are some of the problems that face the interns during the field experience period?

Sometimes a little prejudice, sometimes a little animosity. 


\section{QUESTIONNAIRE}

NAME OF INSTITUTION: Johnson \& Wales College

RANK: Executive Chef. (Grad. of Johnson \& Wales)

DURATION IN THIS TYPE OF POSITION:

NAME: Robert St. Lawrence

PHONE NUMBER AND ADDRESS: $7532 \mathrm{sW} 7$ th St. No. Lauderdale, 33068 $726-3301$

1.A. Students in our Hospitality Management Program are required to complete some kind of field experience.

Yes $\quad$ No

B. What type of field experience, please circle one.
a. On the job training
$\mathrm{X}$
b. Seminars
c. Practicum or internship
d. Work study program
e. Cooperative study

2.A. To satisfy a field experience requirement, a student must complete 600 hours on the job.
a. 100-160 hours
b. 161-220 hours
c. 221-280 hours
d. 281 and above $x$

B. To satisfy a field experience requirement, the student must:
a. Work without pay
b. Work with pay
c. Other (please specify)

3. The supervision of the students enrolled for field experience is done by
a. faculty members
b. employers
c. jointly by $a$ and $b \quad x$
d. others
e. jointly by a and $d$ 
4. Please rank on a scale of 1 to 4 , the importance of those five elements in your curriculum.

I Major or professional courses

2 Professionally related field experience

3 Non-major technical courses

4 science 1

5. Our institution waives the field experience requirement for a position that has no parallel in the hospitality industry.

No

6. Please mark any job positions which would be accepted for the field experience requirement.

$\begin{array}{ll}\text { a. Banquet Manager } & \text { X } \\ \text { b. Maintenance engineer } & \\ \text { c. Dietary personnel } & \text { X } \\ \text { d. Stock clerk } & \text { X } \\ \text { e. Bus boy } & \text { X } \\ \text { f. Fifkt cook } & \\ \text { g. Real estate cook } & \\ \text { h. Night auditor } & \text { X } \\ \text { i. Concession stand operator X } \\ \text { j. Host or hostess }\end{array}$

7. What are the core curriculum requirements for

a. Associate in Science $x$ 1. Hospitality Management

b. Bachelor's degree 2. Demo-Kitchen

c. Master's degree 3. Advanced Kitchen-Cookinc

in Hospitality Management?

8 How is the field experience requirement monitored by your institution?. Please name the methods employed.

Each 100 hr. report is due total of 6 reports, then a grade. 
9. Is there a grade option for the field experience requirement?

$$
\text { A, B, C Grade }
$$

10. In your opinion, is it justifiable to say that field experience and other modified experiences such as seminar, practiclum, the cooperative and the work study programs will not play an important role of closer alliance between the academic and the hospitality industry?

No

11. Is it possible to offer courses in field experience which will enhance the professionally oriented course work, while educators, academic administrators and employers strive to design a common curriculum that is needed to meet the educational and the industry deman's and goals? please comment.

Yes

12. What are some of the problems that face the interns during the field experience period?

Some of the problems is coping with different situations and people that have been working in the operation for a long time. 
APPENDIX B

QUESTIONNAIRE

NAME OF INSTITUTION: Morrison's C.feterias Inc.

RANK: Manager

DURATION IN THIS TYPE- OF POSITIUN: 7 years

NAME : R. P. Keenan

PHONE NUMBER AND ADDRESS: 1455 N.W. 107th AVe., Miami 591-2125

1.A. Students in our Hospitality Management Program are required to complete some kind of field experience.

Yes $\quad$ No

B. What type of field experience, please circle one.

$\begin{array}{ll}\text { a. On the job training } & x \\ \text { b. Seminars } & x \\ \text { c. Practicum or internship } & x \\ \text { d. Work study program } & x \\ \text { e. Cooperative study } & \end{array}$

2.A. To satisfy a field experience requirement, a student must complete hours on the job.
a. 100-160 hours
b. 161-220 hours
c. 221-280 hours
d. 281 and above

$\mathrm{X}$

B. To satisfy a field experience requirement, the student must:
a. Work without pay
b. Work with pay
c. Other (please specify)

3. The supervision of the students enrolled for field experzence is done by
a. faculty members - management
b. employers
c. jointly by $a$ and $b \quad x$
d. others
e. jointly by a and d 
4. Please rank on a scale of 1 to 4 , the importance of those five elements in your curriculum.

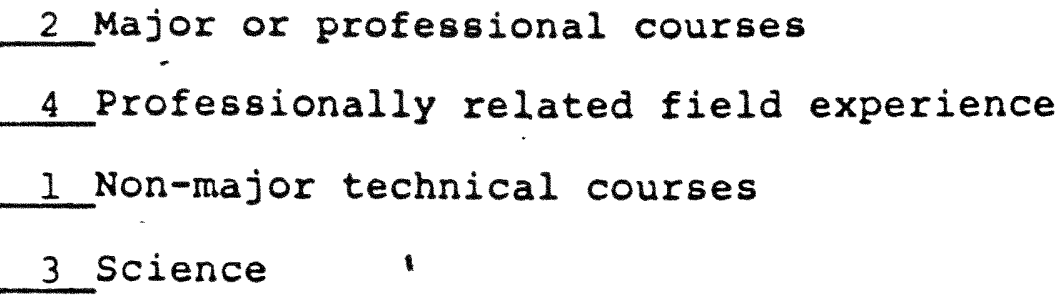

5. Our institution waives the field experience requirement for a position that has no parallel in the hospitality industry.

6. Please mark any job positions which would be accepted for the field experience requirement.
a. Banquet Manager/Production $x$
b. Maintenance engineer
c. Dietary personnel
d. Stock clerk
e. Bus boy
f. First cook
$\mathrm{x}$
g. Real estate cook
h. Night auditor office Mgr. X
i. Concession stand operator $x$
$j$. Host or hostess $x$

7. What are the core curriculum requirements for
a. Associate in science
b. Bachelor's degree
c. Master's degree

in Hospitality Management?

How is the field experience requirement monitored by your institution?. Please name the methods employed.

We use skills Inventory Manual as a guideline for each job knowledge needed. Trainee is then tested on each department as he completes training in them. This is done in conjunction with manager and personnel dept. 
9. Is there a grade option for the field experience requirement?

Yes

10. In your opinion, is it justifiable to say that field experience and other modified experiences such as seminar, practiclum, the cooperative and the work study programs will not play an important role of closer alliance between the academic and the hospitality industry?

No, it definitely plays an important role

11. Is it possible to offer courses in field experience which will enhance the professionally oriented course work, while educators, academic administrators and employers strive to design a common curriculum that is needed to meet the educational and the industry deman's and goals? Please comment.

Yes it is being done

12. What are some of the problems that face the interns during the field experience period?

a. Communication with the work group

b. The physical demands

c. Relating the job knowledge to profit 
APPENDIX B

QUESTIONNAIRE

NAME OF INSTITUTION: Burgher King Corporation

RANK: Restaurant Training Manager

DURATION IN THIS TYPE OF POSITION: 1 year

NAME: ROXie French

PHONE NUMBER AND ADDRESS: 2108 N.W. 59 th Terr., Lauderhill 920-3993 (Office)

1.A. Students in our Hospitality Management Program are required to complete some kind of field experience.

Yes $\quad$ No

B. What type of field experience, please circle one.
a. On the job training $x$
b. Seminars
c. Practicum or internship
d. Work study program
e. Cooperative study

2.A. To satisfy a field experience requirement, a student must complete hours on the job.
a. 100-160 hours
b. 161-220 hours
c. 221-280 hours
d. 281 and above
$\mathrm{X}$

B. To satisfy a field experience requirement, the student must:
a. Work without pay
b. Work with pay
c. Other (please specify)

3. The supervision of the students enrolled for field experience is done by
a. faculty members
b. employers $x$ - Restaurant Manager
c. jointly by a and $b$
d. Others
e. jointly by $a$ and $d$ 
4. Please rank on a scale of 1 to 4 , the importance of those five elements in your curriculum.

LMajor or professional courses
2 Professionally related field experience
4 Non-major technical courses
3 Science

5. Our institution waives the field experience requirement for a position that has no parallel in the hospitality industry.

False

6. Please mark any job positions which would be accepted for the field experience requirement.

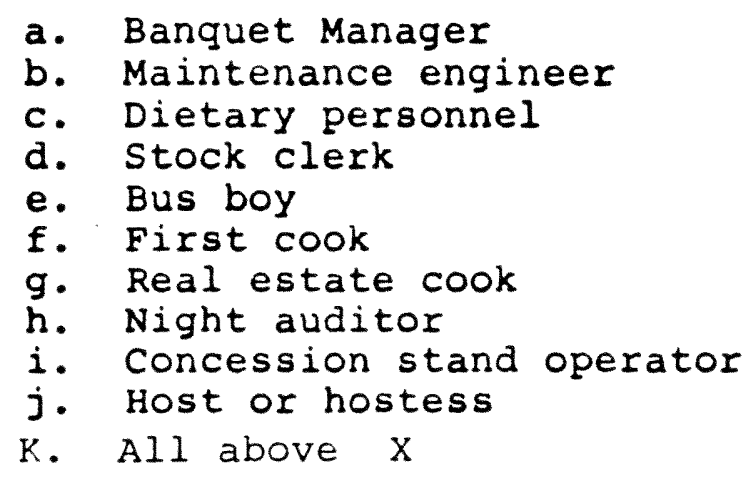

7. What are the core curriculum requirements for
a. Associate in Science
b. Bachelor's degree
c. Master's degree
$\mathrm{N} / \mathrm{A}$

in Hospitality Management?

How is the field experience requirement monitored by your institution?. Please name the methods employed.

It is monitored by the Restaurant Manager"as well as the training Manager, through questioning, written follow up tests, conversations, OTJ performance as well as follow up from District Manager. 
9. Is there a grade option for the field experience requirement?

The trainee is graded by the Training Manager, the RTM on aggressiveness, sense of urgency, awareness, how well he handles the employees, his abilities to handle problems. Both the RTM and the RM have been trained to do this.

10. In your opinion, is if justiable to say that field experience and other modified experiences such as seminar, practicum, the cooperative and the work study programs will not play an important role of closer alliance between the academic and the hospitality industry?

No.

11. Is it possible to offer courses in field experience which will enhance the professionally oriented course work, while educators, academic administrators and employers strive to design a common curriculum that is needed to meet the educational and the industr:'s demands and goals? Please comment.

More people and communication skills.

12. What are some of the problems that face the interns during the field experience period?

1. Frustration over the pace of the business

2. Inabilities to communicate the needs of the restaurant to the employees

3. Inabilities in handling people

4. How to handle problems to complaints

5. Lack of total awareness of the restaurant needs. 
APPENDIX B

QUESTIONNAIRE

NAME OF INSTITUTION: Burger King Corporation

RANK: Assistant Manager

DURATION IN THIS TYPE OF POSITION: $1 / 2$ year

NAME: $\quad$ Sixtus Ayek Ikogor

PHONE NUMBER AND ADDRESS: 2015 Haverhill Ct., West Palm Beach, 33406 $305-439-6515$

1.A. Students in our Hospitality Management Program are required to complete some kind of field experience.

Yes $\quad$ No

B. What type of field experience, please circle one.
a. On the job training $x$
b. Seminars
c. Practicum or internship $\mathrm{x}$
d. Work study program
e. Cooperative study

2.A. To satisfy a field experience requirement, a student must complete hours on the job.
a. 100-160 hours
b. 161-220 hours
c. 221-280 hours
d. 281 and above

B. To satisfy a field experience requirement, the student must:
a. Work without pay
b. Work with pay
c. Other (please specify) A AND B

3. The supervision of the students enrolled for field experience is done by
a. faculty members
b. employers
c. jointly by $a$ and $b$
d. others
e. jointly by a and d

$\mathrm{X}$ 
4. Please rank on a rcale of 1 to 4 , the importance of those five elements in your curriculum.

1 Major or professional courses
2 Professionally related field experience
4 Non-major technical courses
3 Science

5. Our institution waives the field experience requirement for a position that has no parallel in the hospitality'industry.

No

6. Please mark any job positions which would be accepted for the field experience requirement.
a. Banquet Manager $X$
b. Maintenance engineer
c. Dietary personnel $X$
d. Stock clerk
e. Bus boy
f. First cook $x$
g. Real estate cook
h. Night auditor $\mathrm{X}$
i. Concession stand operator $X$
$j$. Host or hostess $X$

7. What are the core curriculum requirements for
a. Associate in Science
- Introduction to Hotel/Mote
b. Bachelor's degree
c. Master's degree
- Accounting Mgmt.
- Marketing
- Computer
- Quantity \& Volume Feeding

in Hospitality Management?

8 How is the field experience requirement monitored by your institution?. Please name the methods employed.

- Weekly reports

- Supervisions out put 
9. Is there a grade option for the field experience iequirement?

Yes Pass/Incomplete

10. In your opinion, is it justifiable to say that field experience and other modified experiences such as seminar, practicum, the cooperative and the work study programs will not play an important role of closer alliance between the academic and the hospitality industry?

No

11. Is it possible to offer courses in fimd experience which will enhance the professionally oriented course work, while educators, academic administrators and employers strive to design a common curriculum that is needed to meet the educational and the industry deman's and goals? please comment.

$Y \in S$

12. What are some of the problems that face the interns during the field experience period?

- Communication

- Inadequate preparation in the food and beverage Aspect of the industry. 


\section{QUESTIONNAIRE}

NAME OF INSTITUTION:

RANK :

DURATION IN THIS TYPE OF POSITION:

NAME :

PHONE NUMBER AND ADDRESS:

1.A. Students in our Hospitality Management Program are required to complete some kind of field experience.

$$
\text { Yes } \quad \text { No }
$$

B. What type of field experience, please circle one.
a. On the job training $x$
b. Seminars
c. Practicum or internship
d. Work study program
e. Cooperative study

2.A. To satisfy a field experience requirement, a student must complete 800 hours on the job.
a. 100-160 hours
b. 161-220 hours
c. 221-280 hours
d. 281 and above

$\mathrm{X}$

B. To satisfy a field experience requicement, the student must:
a. Work without pay
b. Work with pay
c. Other (please specify)
$\mathrm{X}$

3. The supervision of the students enrolled for field experience is done by
a. faculty members
b. employers
c. jointly by $a$ and b
d. others
e. jointly by a and $d$ 
4. Please rank on a scale of 1 to 4 , the importance of those five elements in your curriculum.

Major or professional courses Professionally related field experience Non-major technical courses Science

5. Our institution waives the field experience requirement for a position that has no parallel in the hospitality industry.

No

6. Please mark any job positions which would be accepted for the field experience requirement.
a. Banquet Manager
$\mathrm{X}$
b. Maintenance engineer
c. Dietary personnel
d. Stock clerk
e. Bus boy
f. First cook
g. Real estate cook
h. Night auditor
i. Concession stand operator
j. Host or hostess

7. What are the core curriculum requirements for
a. Associate in Science
b. Bachelor's degree
c. Master's degree

in Hospitality Management?

How is the field experience requirement monitored by your institution?. Please name the methods employed.

Student gets experience and then write a paper upon completion. 
9. Is there a grade option for the field experience requirement?

No -Pass or fail

10. In your opinion, is it justifiable to say that field experience and other modified experiences such as seminar, practicum, the cooperative and the work study programs will not play an important role of closer alliance between the academic and the hospitality industry?

No

11. Is it possible to offer courses in field experience which will enhance the professionally oriented course work, while educators, academic administrators and employers strive to ciesign a common curriculum that is needed to meet the educational and the industry deman's and goals? please comment.

Yes

12. What are some of the problems that face the interns during the field experience period?

No problems. 
NAME OF INSTITUTION:

RANK :

DURATION IN THIS TYPE OF POSITION:

NAME :

PHONE NUMBER AND ADDRESS:

1.A. Students in our Hospitality Management Program are required to complete some kind of field experience.

Yes $\quad$ No

B. What type of field experience, please circle one.
a. On the job training $x$
b. Seminars
c. Practicum or internship
d. Work study program
e. Cooperative study

2.A. To satisfy a field experience requirement, a student must complete hours on the job.
a. 100-160 hours
b. 161-220 hours
c. 221-280 hours
d. 281 and above

$\mathrm{X}$

B. To satisfy a field experience requirement, the student must:
a. Work without pay
b. Work with pay
c. Other (please specify)

3. The supervision of the students enrolled for field experience is done by
a. faculty members
b. employers
c. jointly by $a$ and $b \quad x$
d. others
e. jointly by a and $d$ 
4. Please rank on a scale of 1 to 4, the importance of those five elements in your curriculum.

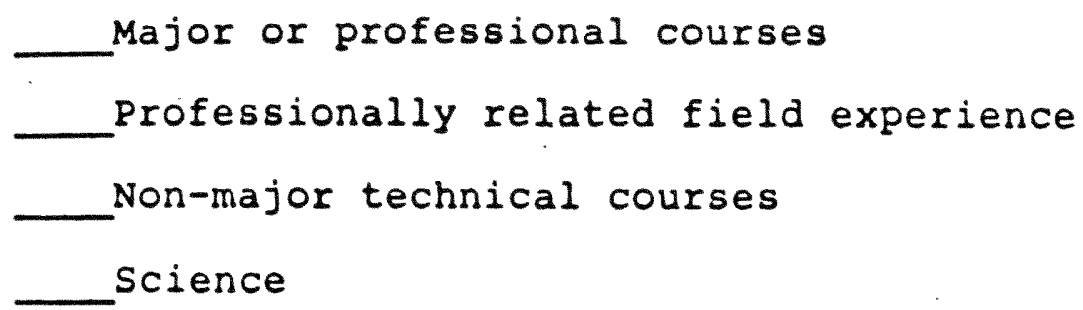

5. Our institution waives the field experience requirement for a position that has no parallel in the hospitality industry.

No

6. Please mark any job positions which would be accepted for the field experience requirement.
a. Banquet Manager
b. Maintenance engineer
c. Dietary personnel
d. Stock clerk
e. Bus boy
f. First cook
$\mathrm{x}$
g. Real estate cook
h. Night auditor $X$
i. Concession stand operator
j. Host or hostess

7. What are the core curriculum requirements for
a. Associate in Science
b. Bachelor's degree
c. Master's degree

in Hospitality Management?

8 How is the field experience requirement monitored by your institution?. Please name the methods employed.

By supervisor and then reporting to the coordinator. 
9. Is there a grade option for the field experience requirement?

No

10. In your opinion, is it justifiable to say that field experience and other modified experiences such as seminar, practicum, the cooperative and the work study programs will not.play an important role of closer alliance between the academic and the hospitality industry?

No

11. Is it possible to offer courses in fibld experience which will enhance the professionally oriented course work, while educators, academic administrators and employers strive to design a common curriculum that is needed to meet the educational and the industry deman's and goals? please comment.

A course in field experience will certainly be a plus.

12. What are some of the problems that face the interns during the field experience period?

No problems. 
NAME OF INSTITUTION:

RANK :

DURATION IN THIS TYPE OF POSITION:

NAME :

PHONE NUMBER AND ADDRESS:

1.A. Students in our Hospitality Management Program are required to complete some kind of field experience.

Yes No

B. What type of field experience, please circle one.
a. On the job training $x$
b. Seminars
c. Practicum or internship
d. Work study program
e. Cooperative study

2.A. To satisfy a field experience requirement, a student must complete hours on the job.
a. 100-160 hours
b. 161-220 hours
c. 221-280 hours
d. 281 and above
$\times 600$

B. To satisfy a field experience requirement, the student must:
a. Work without pay
b. Work with pay
c. Other (please specify)

3. The supervision of the students enrolled for field experience is done by
a. faculty members
b. employers
c. jointly by $a$ and b
d. others
e. jointly by a and $d$ 
9. Is there a grade option for the field experience requirement?

No

10. In your opinion, is it justifiable to say that field experience and other modified experiences such as seminar, practicum, the cooperative and the work study programs will not play. an important role of closer alliance between the academic and the hospitality industry?

No

11. Is it possible to offer courses in find experience which will enhance the professionally oriented course work, while educators, academic administrators and employers strive to design a common curriculum that is needed to meet the educational and the industry deman's and goals? Please comment.

Definitely

12. What are some of the problems that face the interns during the field experience period?

Frustration (since the students have to go out and get the job themselves and then notify school. 
APPENDIX B

QUESTIONNAIRE

NAME OF INSTITUTION:

RANK:

DURATION IN THIS TYPE OF POSITION:

NAME :

PHONE NUMBER AND ADDRESS:

1.A. Students in our Hospitality Management Program are required to complete some kind of field experience. Yes $X$ No

B. What type of field experience, please circle one.
a. On the job training
$\mathrm{x}$
b. Seminars
c. Practicum or internship
d. Work study program
e. Cooperative study

2.A. To satisfy a field experience requirement, a student must complete hours on the job.
a. 100-160 hours
b. 161-220 hours
c. 221-280 hours
d. 281 and above

$\mathrm{X}$

B. To satisfy a field experience requirement, the student must:
a. Work without pay
b. Work with pay
$\mathrm{x}$
c. Other (please specify)

3. The supervision of the students enrolled for field experience is done by
a. faculty members
b. employers
c. jointly by $a$ and $b$
d. others
e. jointly by a and $d$ 
4. Please rank on a scale of 1 to 4, the importance. of those five elements in your curriculum.

1 Major or professional courses

1 Professionally related field experience

1 Non-major technical courses

2 Science

5. Our institution waives the field experience requirement for a position that has no parallel in the hospitality industry.

No

6. Please mark any job positions which would be accepted for the field experience requirement.
a. Banquet Manager
b. Maintenance engineer
c. Dietary personnel
d. Stock clerk
e. Bus boy
f. First cook
g. Real estate cook
h. Night auditor
i. Concession stand operator
j. Host or hostess

7. What are the core curriculum requirements for
a. Associate in Science
b. Bachelor's degree
c. Master's degree
60 credit hrs. 120 credit hrs.

in Hospitality Management?

8 How is the field experience requirement monitored by your institution?. Please name the methods employed.

The student submitts a weekly report on activities carried out each week. 
9. Is there a grade option for the field experience re uirement?

No

10. In your opinion, is it justifiable to say that field experience and other modified experiences such as seminar, practicum, the cooperative and the work study programs will not play an important role of closer alliance between the academic and the hospitality industry?

No

11. Is it possible to offer courses in field experience which will enhance the professionally oriented course work, while educators, academic administrators and employers strive to design a common curriculum that is needed to meet the educational and the indistry deman's and goals? Please comment.

Certainly

12. What are some of the problems that face the interns during the field experience period?

No so far. 
NAME OF INSTITUTION:

RANK:

DURATION IN THIS TYPE OF POSITION:

NAME :

PHONE NUMBER AND ADDRESS:

1.A. Students in our Hospitality Management Program are required to complete some kind of field experience.

Yes $\mathrm{X}$ No

B. What type of field experience, please circle one.
a. On the job training $x$
b. Seminars
c. Practicum or internship
d. Work study program
e. Cooperative study

2.A. To satisfy a field experience requirement, a student must complete hours on the job.
a. 100-160 hours
b. 161-220 hours
c. 22l-280 hours
d. 281 and above

$\mathrm{X}$

B. To satisfy a field experience requirement, the student must:
a. Work without pay
b. Work with pay
c. Other (please specify)
$\mathrm{X}$

3. The supervision of the students enrolled for field experience is done by
a. faculty members
b. employers
c. jointly by $a$ and b
d. others
e. jointly by a and $d$ 
4. Please rank on a scale of 1 to 4 , the importance. of those five elements in your curriculum.

1 Major or professional courses
2 Professionally related field experience
4 Non-major technical courses
3 Science

5. Our institution waives the field experience requirement for a position that has no parallel in the hospitality industry.

No

6. Please mark any job positions which would be accepted for the field experience requirement.

$\begin{array}{ll}\text { a. Banquet Manager } & \mathrm{X} \\ \text { b. Maintenance engineer } & \\ \text { c. Dietary personnel } & \\ \text { d. Stock clerk } & \mathrm{X} \\ \text { e. Bus boy } & \mathrm{X} \\ \text { f. First cook } & \mathrm{x} \\ \text { g. Real estate cook } & \\ \text { h. Night auditor } & \\ \text { i. Concession stand operator } \\ \text { j. Host or hostess }\end{array}$

7. What are the core curriculum requirements for
a. Associate in Science
b. Bachelor's degree
c. Master's degree

in Hospitality Management?

How is the field experience requirement monitored by your institution?. Please name the methods employed.

By employer, supervisor sends a weekly report and student's progress ard then a detailed report by student towards the end of program. 
9. Is there a grade option for the field experience requirement?

$$
\text { No - Pass/Fail }
$$

10. In your opinion, is it justifiable to say that field experience and other modified experiences such as seminar, practicum, the cooperative and the work study programs will not play an important role of closer alliance between the academic and the hospitality industry?

No

11. Is it possible to offer courses in field experience which will enhance the professionally oriented course work, while educators, academic administrators and employers strive to design a common curriculum that is needed to meet the educational and the industry deman's and goals? Please comment.

Yes

12. What are some of the problems that face the interns during the field experience period?

Trying to be accepted so as to be taught correctly on the job. 
V. RESULTS 
RESULTS :

QUESTION 1. Students in our Hospitality Management Program are required to complete some kind of field experience.

Six four-year programs and four two-year programs agreed that they require the field experience. The four year restaurant managers and five students interviewed agreed that their operations require some sort of on-the-job and instructional training. While the latter supported the experience based on the impact of the program on their performance, the proportional correlation between the affirmative answers and the number of respondents were the same in all cases within one percent. Table one shows this correlation:

\begin{tabular}{|c|c|c|c|c|}
\hline \multirow[t]{2}{*}{ TABLE 1.} & \multicolumn{4}{|c|}{$\begin{array}{l}\text { Proportion of two-year and four-year Food-service } \\
\text { and Hotel operations programs Institutes requiring } \\
\text { field experience }\end{array}$} \\
\hline & & YES & NO & TOTAL \\
\hline & Two-year programs $(N=4)$ & 1.00 & -- & 1.00 \\
\hline & Four year programs $(N=6)$ & 1.00 & -- & 1.00 \\
\hline & Restaurant Operations $(\mathrm{N}=2)$ & & -- & 1.00 \\
\hline & Hotel Operations $(\mathrm{N}=1)$ & 1.00 & -- & 1.00 \\
\hline
\end{tabular}

A response from Palm Beach Junior College stress the importance of field experience:

1. The food and lodging industry needs people with experience and devotion to work.

2. Most courses are geared in that direction. The response from Florida state University reaffirms Joseph $N$. Koppel findings; he stated "Our positon has been that although the on-the-job training and vision has some decided benefits, it does not 
provide experience on the executive level. Consequently, on the manager, district manager, and higher levels, (a student's) time is better spent on courses designed to increase his ability to think, to evaluate and to analyze".

The Coordinator of Florida State University Hospitality Management Internship Program puts it this way, "Field experience is definitely critical. This should involve the management and institution teams. The student should also be involved in the decision making process; at least the graduate level.

QUESTION 2. To satisfy a field esperience requirement, a student must complete hours on the job.

only one fourth of the two-year programs require less than 281 hours of field experience, while all the four-year programs require more than 281 hours. (Table 2 illustrates this distribution)

TABLE 2. Proportion of Programs that require a minimum number of 281 clock hours of Field Experience to complete a program.

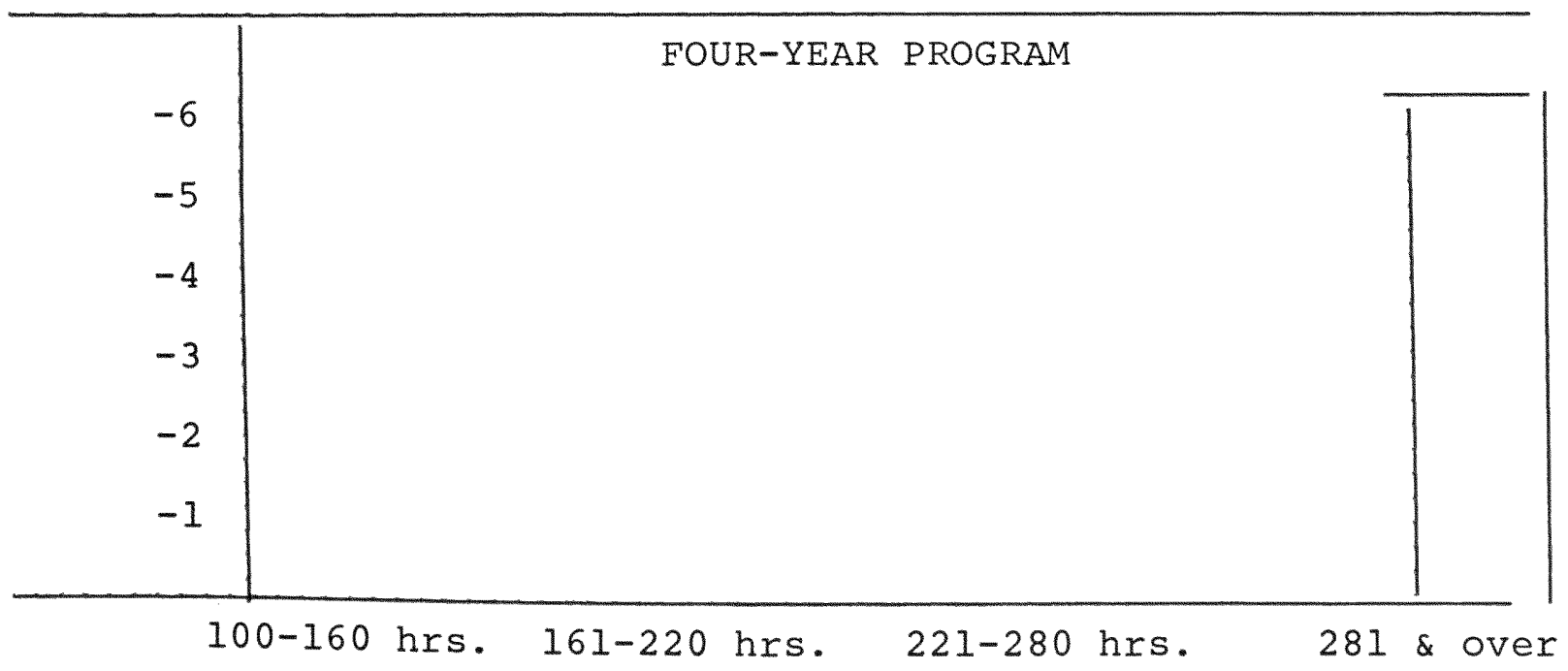




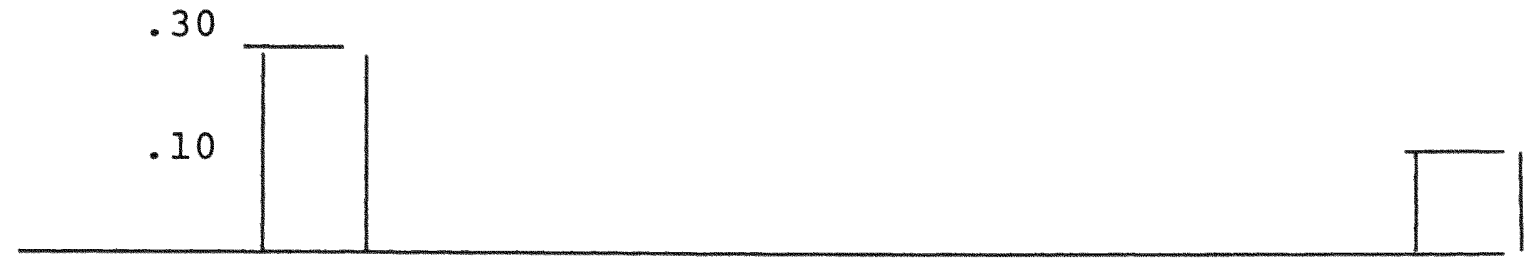

100-160 hrs. 161-220 hrs. 221-280 hrs. 281 \& over

In probing the question further, I found out that most students work beyond the required number of hours. This indicates that the students also realize the importance of field experience and this re-inforces the concept that field experience is valuable.

To satisfy a field experience requirement, the student
a. work without pay
b. work with pay
c. others (please specify)

About $99 \%$ of the four-year and two-year programs agreed that they should work with pay since they render service.

A response from Florida International University had a more broader perspective that students can work with or without pay depending upon the company policy. 
QUESTION 3. The supervision of the students enrolled for field experience is done by:

A majority of both probrams reported that program faculty and employers share the responsibility for supervision. (Table 3 illustrates this consensus)

TABLE 3. Proportion of those given the responsibility for supervision of the student in field experience

\begin{tabular}{lccc}
\hline Person(s) & responsible $\begin{array}{l}\text { Two-year } \\
\text { Program }\end{array}$ & $\begin{array}{l}\text { Four-year } \\
\text { Program }\end{array}$ & $\begin{array}{c}\text { Rest. } \\
\text { Hotel }\end{array}$ \\
\hline & $\mathrm{N}=4$ & $\mathrm{~N}=6$ & $\mathrm{~N}=6$ \\
$\begin{array}{l}\text { Program Faculty } \\
\begin{array}{l}\text { Employer or his represent- } \\
\text { Both }\end{array}\end{array}$ & .50 & .17 & -.17 \\
TOTAL & .50 & .66 & 1.00 \\
& 1.00 & 1.00 & --- \\
\hline
\end{tabular}

The majority concensus indicate the importance of monitoring the program. It also indicates that for the program to operate efficiently it needs constant monitoring and updating.

QUESTION 4. Please rank on a scale of 1 to 4 the importance of these elements in your curriculum.

Both the two and four year programs indicated that professional, academic subjects are the most important part of the Hotel and Foodservice management curriculum, they also felt that a highly specialized area of education; one that required a good deal of academic and field experience is a must. 
TABLE 4. Illustrates the importance to course experiences in two and four-year porgrams. Two-year programs $(N=4) \quad$ Four-year programs $(N=6)$

\begin{tabular}{|c|c|c|c|c|c|c|c|c|c|c|}
\hline & 1 & 2 & $\beta$ & 4 & Rating Total & 1 & 2 & 3 & 4 & Rating Total \\
\hline Major or Professional courses & 1.0 & - & - & - & 1.00 & .80 & .20 & -- & L- & 1.00 \\
\hline $\begin{array}{c}\text { Professionally Related Field } \\
\text { Exp. }\end{array}$ & -- & 1.0 & - & - & 1.00 & .30 & .20 & .50 & - & 1.00 \\
\hline Non-major technical Courses & -- & - & .25 & .75 & 1.00 & .20 & -- & -- & .80 & 1.00 \\
\hline Science & -- & - & .75 & 25 & 1.00 & .01 & .33 & .33 & .33 & 1.00 \\
\hline
\end{tabular}


QUESTION 5. Our institutions waives the field experience requirements for a position that has no parallel in the hospitality industry.

All the participants in this research indicated that they do not waive any type of field experience that has no parallel in the hospitality industry. On probing the question further, the restaurants and lodging operations indicated that no amount of experience is good enough to substitute for their concept. Hence, employees and interns have to undertake their own operation training. Here again, Florida International University indicates they do waive the requirement if one had worked in a banquet management position for about three or more years.

QUESTION 6. Please mark any job positions which would be accepted for the field experience requirement.

The response to this question varied as regards its participants while most four year programs marked the following: Banquet Manager, Cook, Night Auditor.

The two year program marked the following: Banquet Manager, Dietary Personnel, Stock Clerk, Bus Boy, Cook, Night Auditor and Concession Stand Operator and Host or Hostess.

Only Florida International University indicated that the accepted position among this category is Banquet Manager. The differences in response to this question indicates what each institution considers acceptable for field experience. 
QUESTION 7. What are the core curriculum requirements for Hospitality Management?

The researcher noted after the project was almost completed that this question was too broad. It was geared however, to the three levels indicated in the questions. The courses mentioned by $50 \%$ of the two year programs include: Marketing, Introduction to Hospitality, Quantity Food Preparation, and Accounting and Human Relation Management.

On the other hand, $40 \%$ of the four year institutions left out this question and indicated to the researcher that he did not make himself clear. Denver University, participant, indicated that the core courses for hospitality management are basically the same, but are sometimes given fanciful names and prefixes. The industry position was stated by Roxie of Burger king that all hospitality management core curriculum are helpful but noted that her company does not waive the basic because one has completed a similar course in college.

QUESTION 8. How is the field experience requirement monitored by your institution? please name the methods employed.

This question was included to find out how committed an institution is to the field experience requirement. It is also tied to question 3. About $75 \%$ of the four year programs indicated that supervision is done by the employer/institution program Director. 
The remaining $25 \%$ allow employers to monitor the program, but insist that their students submit weekly written paper to demonstrate understanding and competence of the job assignment performed. About 95\% of the two year program response was that the field experience was monitored by the employer since the student grade was given by the supervisor which the student worked with.

The industry response as presented by Roxie of Burger King was that the field experience is monitored by the Restaurant Manager, training supervisor and district manager. Progress was measured by designed questions for the various positions.

\section{QUESTION 9. Is there a grade option for the field experiment} requirement?

The response to this question varied for most institutions. While $95 \%$ of the four year institutions require field experience, the grade of pass/fail is awarded the student upon completion. However, this grade is not computed into the student's grade point average. The other $5 \%$ include the grade awarded into the grade point average of the student.

A majority of the two year programs response was that, a grade of $A$ through $F$, is based on the input of the immediate supervisor of the student during the field experience period. 
The industry position on grade option is also pass/fail. This pass/fail serve to show the areas the candidate needs to improve. It gives management the input needed to determine whether the employee involved will make it with their company or not.

QUESTION 10. In your opinion, is it justifiable to say that field experience and other modified experiences such as seminars, practicum, the cooperative and work study programs will not play an important role of closer alliance between the academic and hospitality industry?

All the two and four year programs responses were that it was not justifiable to say that field experiences and other modified experiences such as seminar practicum, the cooperative and work study programs will not play an important role of closer alliance between the academic and hospitality industry.

Probably, Professor V. Chandrasekar of University of Denver response stand out for all the two groups of institutions, "No, it is not justifiable because any education without experience is as bad as a farmer without any equipment".

QUESTION 11. Is it possible to offer courses in field experience which will enhance the professionally oriented course work, while educators academic administrators and employers strive to design a common curriculum that is needed to meet the educational and industrial demands and goals? 
Here again, all the participants agreed that it is possible to offer courses in field experience which will enhance the professionally oriented course work, while educators, academic administrators and employers strive to design a common curriculum that is needed to meet the educational and industrial needs and goals.

The insight is already in the making, although progress has been made, there is still a lot to be improved upon to bring the hospitality industry in line with the needs of the $80^{\prime} \mathrm{s}$ and $90^{\prime} \mathrm{s}$ obeserved Ayek.

QUESTION 12. What are some of the problems that face the interns during the field experience period?

The researcher felt that the investigation into the impact of field experience in hospitality education will not be complete without probing the problem that eminate during such period. Although $80 \%$ of the two and four year programs indicate they have had a number of problems ranging from:

1. Sometimes gets slow and the students are laid off, this gets frustration in the ball game.

2. Trying to match the students with the property,

3. Trying to make the operations involve these students in making management decisions.

4. Finding jobs for the students interns, most institutions do not provide such luxury. 
5. Lack of attention by industry supervisors.

6. Working with other employees.

\section{CONCLUSION}

All institutions consider the impact of field experience in hospitality education as a very important requirement in hospitality management program curriculum. This research clearly illustrates that field experience is second in importance only to a student's professional course work.

This conclusion was arrived at on the response of the participants to the question whether such field experience and others such as seminar-practicum, the cooperative and the work study programs will not play an important role of a closer alliance between the academic and hospitality industry. While, the first hypothesis was not proven, the second hypothesis was.

All the participants agreed that it is justifiable to say that it is possible to offer courses in field experience which will enhance the professionally oriented course work, while educators and employers strive to design a curriculum that is needed to meet the educational and the industry's demands and goals, thus, proving the hypothesis.

\section{RECOMMENDATION}

Although one of the hypothesis was proved, I feel that there is still very little done to include the field experience as a core curriculum course in most institutions. It is true 
that such field experience has little to contribute to landing a better job upon graduation; it certainly looks good in your resume. Not very much has been written on this subject in the hospitality industry, but field experience in any field helps to bridge the missing link between academics and the industry in question.

While a few writers have written about field experience, it is my hope that others can compound the already available literature and thereafter expand this concept to better educate the industry and academic administrators on the importance of field experience in years to come. 
VI. APPENDICES 
A SELECTED BIBLIOGRAPHY

Dynamics of the Chain Restaurant Market, (Chicago: Technomic Consultants, 1982).

Ferrence, Eugene A. Towards a Definition of Training, The Cornell Hotel Restaurant Association Quarterly, November, 1980.

Leedy, Paul D. Practical Research, 2nd ed., MacMillan Publishing Company, Inc., 1980.

Morgan, William J. "Definition and Effects of Attitude", Hospitality Personnel Management, CBI Publishing Company, Boston, Massachusetts, 1979.

Powers, Thomas "The Emergences of New Base of Operation: Complex Foodservice System", The Cornell Hotel Restaurant Administration Quarterly, November 1979.

Russell, R. B. Changing Programs in Business Education Forum, December 1974 .

Scriven, Jolene D. et al. Summary Report of National Study of Word Processing Installations in Selected Business Organizations, st. Peter, MN: Delta Pi Epsilon 1981.

Stitt, Wanda L. Office Technology Demands Curriculum Revolution, Business Forum, December 1982.

The Journal of Hospitaltiy Education, Vol. 1, June 1976. 
VITAE

Peter Okon Agbomi was born on July 20, 1957 at Adadama Obubra, Cross River state of Nigeria. I attended E.C.C. School, Noyo Ikwo, Abakaliki where I obtained the Eastern Nigeria First School Learning Certificate in 1968.

I was admitted into Izzi High School, Abakaliki on March 10, 1970. In June 1974, I obtained my West African School Certificate. After the High School certificate examination, I took appointment as a Motor Licensing Officer with the Cross River State Motor Licensing Office, Calabar. Three years later I was awarded a Cross River State government scholarship for the academic year 19771978 to study Hotel/Motel Management at the College of Boca Raton, Florida.

On September 3, 1979, I arrived in the United States to resume studies. A year and half later I obtained my Associates in Science Diploma in Hotel/Motel Management.

While a student at the college of Boca Raton, I worked for experience as a dishwasher with Nag's Head Restaurant, and as a bus boy with Red Lobster at Boca Raton. I have also worked as a concession stand personnel, Banquet Manager for Interstate United Corporation, Volume Services Division at Pompano Park from 1980 to the present date. 
On January 9, 1981 I transferred to Florida International University, Miami, Florida to complete the Bachelor's Degree program for which the award was made. I currently hold a B.S. Degree in Hospitality Management, and enrolled in the Master's Degree program at the Florida International University, Miami, Florida. 